\title{
THE HORSESHOE CREEK DISTRICT OF THE TETON BASIN COAL FIELD, FREMONT COUNTY, IDAHO.
}

By E. G. WoodrufF.

\section{INTRODUCTION.}

From time to time during the last six or eight years there have been persistent rumors that a large field of high-grade coal lies southeast of St. Anthony. As the development of such a field would be of great advantage to a large tributary region containing extensive mining and agricultural developments, and as samples from the field seemed to corroborate the rumor regarding the quality of the coal, the writer in 1912 made a hasty examination of the field to determine its prospective value. He found that the reports concerning the quality of the coal were substantially correct, but that the beds are so broken by faults and the area known to be underlain by the beds is so small that the field will probably never supply more than the local market and can not become a factor in the development of the general region of the Snake River valley.

The location and extent of the Teton Basin coal field and the position of the Horseshoe Creek district are shown on the index map (fig. 12). The area here described lies 25 miles southeast of St. Anthony, 10 miles southwest of Haden, a village on the Teton branch of the Oregon Short Line Railroad, and a little farther west of Driggs, a larger town on the same railroad. It embraces the upper part of Horseshoe Creek drainage basin and extends northward across the south fork of Packsaddle Creek. As shown on Plate XXII (p. 388) the district covers about 6 square miles in four townships as follows:
T. 4 N., R. 43 E., 1 square mile:
T. 5 N., R. 43 E., 3 square miles.
T. 4 N., R. 44 E., 1 square mile.
T. 5 N., R. 44 E., 1 square mile.

Only a small part of the 6 square miles, however, contains coal beds which the miners in the field consider thick enough to work under present conditions.

The Horseshoe Creek district has sometimes been called the St. Anthony coal field, because some of the coal has been marketed in that town, and,also because prior to the construction of the railroad 


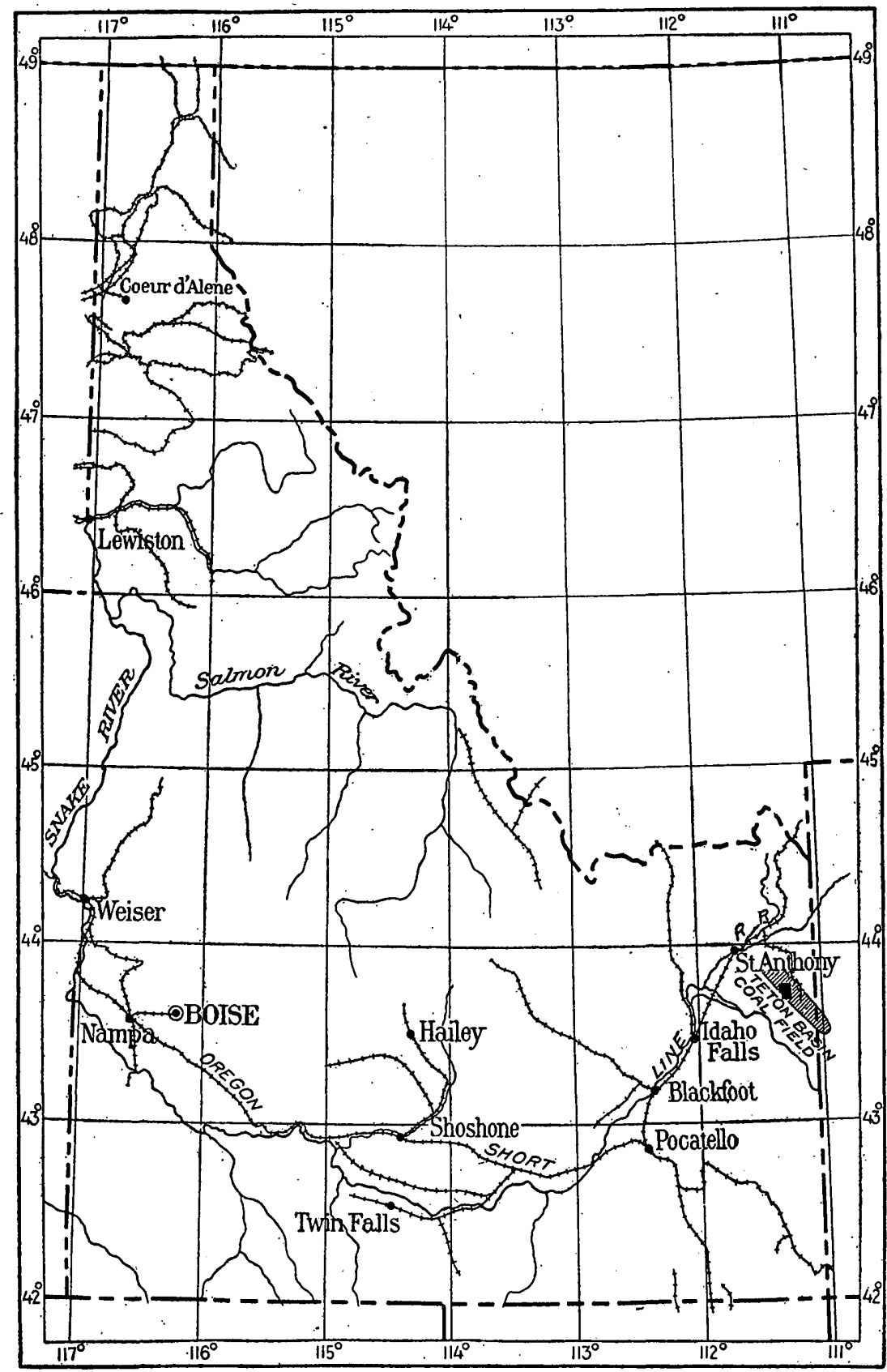

FIGURE 12.-Map showing location of the Horseshoe Creek district of the Teton Basin coal field; Fremont County, Idaho. 
in the Teton Basin in the fall of 1912 St. Anthony was the gateway of the entire region. For two reasons this designation seems inappropriate-first, the area considered is only a small part of a large though indefinite field, and, second, the name applied to it is the name of a town 25 miles away. In this report the area is considered as a district of the Teton Basin coal field. This field embraces the western part of the Teton Basin and the western slope of the Big Hole Mountains. (See index map, fig. 12.) No coal has yet been found in the main part of the basin, which, however, must be considered as a possible coal field because rock formations that are coal bearing elsewhere underlie the basin and probably contain coal. It is believed that coal may be found by drilling or other means of deep prospecting. The Horseshoe Creek district is the only part of the field in which coal is now mined for market.

\section{SURFACE FEATURES.}

The surface of the district is characterized by steep slopes which are trenched by narrow steep-sided valleys. On the west the district is bounded by an escarpment which rises to a height of nearly 1,000 feet and trends north-south near the line of a great fault, shown by a broken line on Plate XXII. This escarpment is so steep that its ascent is difficult except at a few places where the rocks have broken down more completely than elsewhere and form a talus slope. From the foot of the escarpment the surface slopes northeastward to the valley of the north fork of Horseshoe Creek, in the main part of the district. From the floor of this valley there is an almost equally steep ascent to the top of a sharp crested ridge, shown by hachures on Plate XXII. From the summit of the ridge the surface slopes gently northeastward to the valley portion of the Teton Basin. The topographic features are in part shown in profile by the cross section in Plate XXII. These dominant features are modified in a minor way by streams that rise along the escarpment and flow northward in narrow steep-sided valleys, some of which are as much as 100 feet deep. Packsaddle Creek is the largest stream in the northern part of the district, and the two branches of the south fork of Horseshoe Creek are the largest in the southern part. The southern part of the district is also traversed by the main branch of Horseshoe Creek, which leaves the district through a narrow-bottomed, rather steep-sided valley. This valley affords a fairly easy grade for a wagon road into the field.

The coal-bearing part of the field is well watered, containing many small springs and perennial creeks. The surface is covered with a moderately thick growth of trees, mostly aspen and pine, which furnish an abundance of timber that is excellently suited for mine use. 


\section{GEOLOGY. \\ STRATIGRAPHY.}

The rocks of the district comprise limestone, shale, and quartzite of Paleozoic age; sandstone, shale, and coal beds' of Mesozoic age; and lava. In the Paleozoic rocks the limestone is mostly hard gray crystalline and locally somewhat fossiliferous; the quartzite is hard and light colored; and the shale is mostly soft and contains only a rather small quantity of sand. In the Mesozoic rocks the sandstone is only moderately hard and is either gray or buff colored; the shale is soft, generally very sandy, and locally carbonaceous. The coal beds are described later in this report. Lava forms the surface rock over the northern and northeastern part of the district.

No detailed stratigraphic section was measured, because neither the top nor bottom of the coal-bearing strata is exposed. The bottom of the formation lies in a valley where the older rocks are concealed by surface débris, brush, and timber, and the top, which lies along the fault, is effectually concealed by débris which falls from the escarpment. However, sufficient stratigraphic data were obtained to show that the Paleozoic strata occur mostly in thick beds, whereas some of the beds of the Mesozoic sandstone are thick and others are thin and shaly.

A determination of the age of the rocks is based on two collections of fossils, one from the top of the escarpment in the west half of sec. 36, T. 5 N., R. 43 E., and the other from the Brown Bear mine. G. H. Girty reports that the first collection contains zaphrentoid corals, Spirifer, and Compositæ, probably belonging to the Madison limestone. The collection from the Brown Bear mine, according to T. W. Stanton, includes Cardium, Lucina, and Corbula, which suggest a correlation of these strata with the Mesaverde formation of the Rock Springs field or possibly the Adaville formation of southwestern Wyoming. These identifications show that the rocks of the escarpment are Paleozoic and that the coal-bearing rocks in the center of the district belong to the Cretaceous system of the Mesozoic era. Fossils were not found in the eastern part of the district, but the stratigraphic position, thickness, and lithology of at least two of the beds exposed in the high ridge in the eastern part of the field are the same as those of beds in the escarpment; hence it is inferred that the strata at the two places are the same and that both are Paleozoic. The beds in the extreme eastern part of the field have the same lithologic character as some of the Mesozoic beds of this district.

The areal distribution of the Cretaceous is shown approximately on Plate XXII, but as the area was examined chiefly to determine the coal resources, the non coal-bearing rocks, which include both Paleozoic sedimentary beds and rather recent lava flows, were mapped as a unit and are represented by the cross-lined pattern on Plate XXII. 


\section{STRUCTURE.}

As shown by the dip and strike symbols and by cross section on Plate XXII, the rocks in the main part of the district dip steeply to the southwest, whereas the strata on the east side are only slightly inclined and those on the west are horizontal. In the southern part of the district the structure is complicated, but in general the rocks dip steeply to the north. The structure of the sedimentary rocks in the northern part of the district is concealed beneath recent lava flows. The most probable interpretation of the very diverse structural phenomena is that a great fault lies along the western margin of the field (see Pl. XXII), with the downthrow on the east and the upthrow on the west, and that on the east side of the district there is a similar, perhaps equally profound, fault, along which the movement has been in the same direction. Between these two faults lies a large block of strata that is tilted downward to the west. (See cross section, Pl. XXII.) The existence of the western fault can be proved by unmistakable evidence. The amount of throw along the fault is great; according to one method of estimation it is as much as 10,000 feet. Though the fault in the eastern part of the field is concealed by débris, its existence is inferred from the fact that the dip of the rocks near the center of sec. 32 , T. 5 N., R. 44 E., is much greater than that of those in the SE. $\frac{1}{4}$ sec. 28 of the same township. This difference in structure is especially noticeable when the discordance in dip is considered in connection with the relative ages of the strata at the two points. In sec. 32 the rocks are of Paleozoic age and at least 2,000 feet lower stratigraphically than those at the other locality. To reach their present relative positions the beds must have been very -sharply bent upward a little west of location 15 , then downward toward the west after considerable altitude was reached, or else they were faulted. It is believed that the space is too small to permit the necessary folding, and therefore it is thought that the strata have been faulted.

If there are two great faults in the district, as stated above, the rocks between them constitute a fault block which is sharply tilted to the west, as previously explained. In view of the evidence this seems probable, and the cross section on Plate XXII is drawn on that basis.

Besides the major breaks mentioned above there are many minor faults, which have been found whercver the strata are exposed over any considerable area. The abundance of the faults at some places is shown by the plan of the Brown Bear mine, presented at the bottom of Plate XXII. The horizontal extent of the minor faults ranges from a few rods to as much as half a mile and the amount of throw from a few inches to many feet. The effect of these structural movements on the coal beds is discussed later. 


\section{THE COAL.}

\section{CHARACTER AND DISTRIBUTION.}

As shown on Plate XXII, the coal beds outcrop along the slope at the foot of the escarpment and extend downward to the fault in the western part of the field. As the beds are faulted and the outcrops badly covered, it is impossible to trace them for any considerable distance, but certain key rocks were found which assist in the correlation of the beds. A probable connection of the beds at the south end of the field with those exposed in the center and north end is shown on the map. In examining this map, however, it should be borne in mind that the line shows only approximately the position of the outcrop. The exact position can be determined only by a system of prospecting which will explore the bed below the surface. The coal beds occur in two groups about 1,100 feet apart stratigraphically, the lower group being represented at locations $5,6,7,9,10$, and 13 on the map and the upper at locations 8 and possibly 1, 2, 3, and 11. It is probable that the so-called upper group contains only one bed and that the apparent occurrence of more than one bed is due to faulting, which has duplicated its outcrop. The lower group consists of three beds in the northern part of the field, one in the central, and two in the southern part. From the difference in the number of beds in the groups at different localities it is evident that the beds are not continuous. They also differ in thickness and character, but the data obtained do not show conclusively to what extent. The difference is indicated, in part, however, by a comparison of the two sections measured in the Brown Bear mine, 1,200 feet apart, one having a total thickness of 4 feet 5 inches and the other 5 feet 3 inches. These sections are presented on page 387 of this report.

The coal is black and hard, but, as would be expected in a region where so much faulting has taken place, it is badly broken. In mining a large percentage of it comes out fine, and even the larger pieces are so shattered that they do not stand handling well. The coal is bituminous and rather free from impurities, but noncoking, according to the agate-mortar test. The chemical properties of the coal are presented in the following table of analyses, which also shows analyses of samples from other fields for comparison.

The sampling was done according to the regulations of the Bureau of Mines, ${ }^{1}$ which in brief requires that the face to be sampled must be cleared of weathered coal, powder stains, and the like, and then a channel cut across the bed to obtain the sample, at the same time large partings and lumps of impurities being rejected. The sample is collected on a sampling cloth, broken up to pass through a half-inch mesh sieve, mixed thoroughly, quartered, mixed again, and

\footnotetext{
1 For a detailed discussion of the method of coal sampling, see Holmes, J. A., The sampling of coal in the mine: Bur. Mines Technical Paper 1, 1911.
} 
finally the sample is placed in a sealed can, to be forwarded to the chemical laboratory.

Analyses of coal samples from the Horseshoe Creek district, Teton Basin coal field.

[Made at the Pittsburgh laboratory of the Bureau of Mines, A. C. Fieldner, chemist in charge.]

\begin{tabular}{|c|c|c|c|c|c|c|c|c|c|c|c|c|c|c|}
\hline \multirow[b]{2}{*}{ Locality. } & \multirow{2}{*}{ 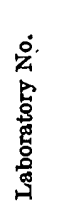 } & \multirow{2}{*}{ 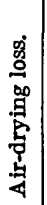 } & \multirow{2}{*}{ 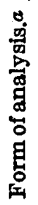 } & \multicolumn{4}{|c|}{ Proximate. } & \multicolumn{5}{|c|}{ Ultimate. } & \multicolumn{2}{|c|}{$\begin{array}{l}\text { Heating } \\
\text { value. }\end{array}$} \\
\hline & & & & 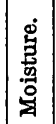 & 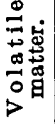 & 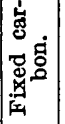 & ક્બું & 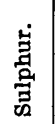 & 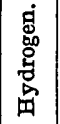 & 客. & 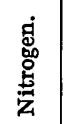 & $\begin{array}{l}\text { 怘 } \\
\text { 总 } \\
0\end{array}$ & 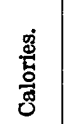 & 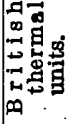 \\
\hline Brown Bear mine..... & 15115 & 8.3 & $\begin{array}{l}\mathbf{A} \\
\mathbf{B} \\
\mathbf{C} \\
\mathbf{D}\end{array}$ & $\begin{array}{r}11.5 \\
3.4 \\
\cdots . . \\
\cdots . . \\
\end{array}$ & $\begin{array}{l}37.2 \\
40.6 \\
42.0 \\
44.2\end{array}$ & \begin{tabular}{|l|}
47.0 \\
51.3 \\
53.1 \\
55.8
\end{tabular} & $\begin{array}{c}4.30 \\
4.69 \\
4.86 \\
\cdots \cdots\end{array}$ & $\begin{array}{r}0.54 \\
.59 \\
.61 \\
.64\end{array}$ & \begin{tabular}{|l|}
$\mathbf{5} .94$ \\
$\mathbf{5 . 4 7}$ \\
$\mathbf{5 . 2 7}$ \\
$\mathbf{5 . 5 4}$
\end{tabular} & $\begin{array}{l}68.09 \\
74.25 \\
76.89 \\
80.82\end{array}$ & $\begin{array}{l}1.40 \\
1.53 \\
1.58 \\
1.66\end{array}$ & \begin{tabular}{|l|}
19.73 \\
13.47 \\
10.79 \\
11.34
\end{tabular} & $\begin{array}{l}6,720 \\
7,325 \\
7,590 \\
7,975\end{array}$ & $\begin{array}{l}12,090 \\
13,190 \\
13,660 \\
14,360\end{array}$ \\
\hline Horseshoe mine........ & 15116 & 4.3 & $\begin{array}{l}\mathbf{A} \\
\mathbf{B} \\
\mathbf{C} \\
\mathbf{D}\end{array}$ & $\mid \begin{array}{c}7.7 \\
3.6 \\
\cdots . . \\
\cdots . .\end{array}$ & $\begin{array}{l}39.7 \\
41.5 \\
43.0 \\
44.1\end{array}$ & $\mid \begin{array}{l}50.4 \\
52.6 \\
54.6 \\
55.9\end{array}$ & $\begin{array}{c}2.2 \\
2.3 \\
2.4 \\
\ldots . .\end{array}$ & $\begin{array}{l}.38 \\
.40 \\
.41 \\
.42\end{array}$ & & & & & $\begin{array}{l}7,155 \\
7,475 \\
7,755 \\
7,945\end{array}$ & $\begin{array}{l}12,880 \\
13.460 \\
13,960 \\
14,300\end{array}$ \\
\hline $\begin{array}{l}\text { Union Pacific mine, } \\
\text { No. 1, Rock Springs, } \\
\text { Wyo. }\end{array}$ & 5358 & 2.3 & $\begin{array}{l}\text { A } \\
\text { B } \\
\mathbf{C} \\
\text { D }\end{array}$ & $\begin{array}{c}8.5 \\
6.4 \\
\ldots . . \\
\ldots . .\end{array}$ & $\begin{array}{l}35.6 \\
36.4 \\
38.9 \\
41.4\end{array}$ & $\mid \begin{array}{l}50.4 \\
51.6 \\
55.1 \\
58.6\end{array}$ & $\begin{array}{c}5.48 \\
5.61 \\
5.99 \\
\ldots . .\end{array}$ & $\begin{array}{l}.78 \\
.80 \\
.85 \\
.90\end{array}$ & $\begin{array}{l}5.36 \\
5.22 \\
4.82 \\
5.13\end{array}$ & $\begin{array}{l}66.15 \\
67.71 \\
72.32 \\
76.93\end{array}$ & $\begin{array}{r}1.19 \\
-1.22 \\
1.30 \\
1.38\end{array}$ & \begin{tabular}{|l|}
21.04 \\
19.44 \\
14.72 \\
15.66
\end{tabular} & $\begin{array}{l}6,575 \\
6,730 \\
7,185 \\
7,645\end{array}$ & $\begin{array}{l}11,830 \\
12,110 \\
12,940 \\
13,760\end{array}$ \\
\hline $\begin{array}{l}\text { Diamondville No. } 1 \\
\text { mine, Kemmerer, } \\
\text { Wyo. }\end{array}$ & 2284 & 1.3 & $\begin{array}{l}\mathbf{A} \\
\mathbf{B} \\
\mathbf{C} \\
\mathbf{D}\end{array}$ & $\begin{array}{c}5.1 \\
3.9 \\
\cdots . . \\
\cdots .\end{array}$ & $\begin{array}{l}40.5 \\
41.0 \\
42.7 \\
44.9\end{array}$ & \begin{tabular}{|l|}
49.8 \\
50.4 \\
52.4 \\
55.1
\end{tabular} & $\begin{array}{r}4.61 \\
4.67 \\
4.86 \\
\cdots . . .\end{array}$ & $\begin{array}{l}.49 \\
.50 \\
.52 \\
.54\end{array}$ & $\begin{array}{l}5.63 \\
5.56 \\
5.33 \\
5.61\end{array}$ & $\begin{array}{l}72.95 \\
73.91 \\
76.89 \\
80.82\end{array}$ & $\begin{array}{l}1.18 \\
1.20 \\
1.24 \\
1.31\end{array}$ & $\begin{array}{l}15.14 \\
14.16 \\
11.16 \\
11.72\end{array}$ & $\begin{array}{l}7,200 \\
7,295 \\
7,590 \\
7,980\end{array}$ & $\begin{array}{l}12,960 \\
13,140 \\
13,660 \\
14,360\end{array}$ \\
\hline $\begin{array}{l}\text { Wasatch mine, Coal- } \\
\text { ville, Utah. }\end{array}$ & 2408 & 6.9 & $\begin{array}{l}\mathbf{A} \\
\mathbf{B} \\
\mathbf{C} \\
\mathbf{D}\end{array}$ & $\mid \begin{array}{r}13.9 \\
7.5 \\
\cdots . . \\
\ldots . .\end{array}$ & $\begin{array}{l}38.0 \\
40.8 \\
44.1 \\
46.5\end{array}$ & \begin{tabular}{|l|}
43.7 \\
46.9 \\
50.7 \\
53.5
\end{tabular} & $\begin{array}{l}4.4 \\
4.8 \\
5.2\end{array}$ & $\begin{array}{l}1.03 \\
1.11 \\
1.20 \\
1.27\end{array}$ & & & & $\begin{array}{l}\cdots \cdots \cdot . \\
\cdots \cdots \cdot . \\
\cdots \cdots\end{array}$ & $\begin{array}{l}6,080 \\
6,530 \\
7,060 \\
7,445\end{array}$ & $\begin{array}{l}10,940 \\
11,750 \\
12,710 \\
13,410\end{array}$ \\
\hline
\end{tabular}

$a$ The form of analysis represented by A, B, C, and D is as follows: A, coal as obtained in the mine; B, coal dried at a temperature of $30^{\circ}$ to $35^{\circ} \mathrm{C}$.; C, moisture-free coal; D, coal free from moisture and ash.

Sample No. 15115, from the Brown Bear mine, was taken from the end of the north entry, 950 feet from the portal, where mining had been done recently and where the coal was unweathered. The sample is believed to represent the coal in its normal condition. For section of coal bed where sampled see page 387 .

Sample No. 15116, from the abandoned Horseshoe mine, was moderately weathered. It was taken at a point about 200 feet from the portal, from a face which had been exposed for more than a year. The surface was cleaned until apparently fresh coal was obtained, but it seems probable that some change, which did not alter the physical appearance of the coal, must have taken place, because the mine is in a dry climate and had remained open to the unrestricted circulation of the air for a long time. It seems most probable that this exposure to the air had resulted in partial oxidation which decreased the heat value below that of unaltered coal. Nevertheless the sample gave a higher calorific value than the unweathered coal from the Brown Bear mine. This is probably to be explained in part by the smaller amount of ash in the Horseshoe sample. For section of bed where sampled see page 387 .

$$
365^{\circ}-\text { Bull: } 541-14-25
$$




\section{DEVELOPMENT.}

There are two producing mines in the field, the Brown Bear mine (location 9) and the Boise (location 8). ${ }^{1}$ Mining and prospecting have been done at other places but at present no development work is in progress. At the northern end of the field, along Packsaddle Creek, there are several abandoned openings, and in the southern part there are two abandoned mines.

Location 1.--At location 1 there is a caved drift. The bed is reported to be 9 feet thick and to terminate at a fault. It is probable that the report of the thickness is exaggerated or that it is abnormal, the coal being squeezed into a pocket. A bed exposed at one place near the portal of the drift is 14 inches thick, but this may not be the bed reported to have been encountered farther back.

Location 2.-At location 2 there is a dump composed in part of coal. The opening from which the coal came is caved, hence no data as to the character of the bed were obtained.

Location 3.-At location 3 there is a prospect pit 6 feet deep in which a coal bed is exposed. The coal occurs in two benches separated by 10 inches of shale, the upper bench being 19 inches thick and the lower 11 inches. The character of the bed is shown by section 3 on Plate XXII.

Location 4.-At location 4 there is an abandoned entry in which 40 inches of badly crushed coal is exposed. At this place the bed appears to have been distorted, hence the normal thickness could not be determined.

Locations 5, 6, and 7.-At locations 5, 6, and 7 there are prospect pits in which sections of the coal beds exposed are as follows: At location 5, 40 inches of coal; at location 6,13 inches of coal; at location 7, in. two benches of coal, 8 inches thick, separated by a 3-inch parting of very impure coal. Graphic sections of these beds are shown in Plate XXII.

The Boise mine (location 8).-The Boise mine consists of a rock tunnel 150 feet long, crosscutting the strata, and an entry 200 feet long extending along the bed from the point where the tunnel enters the coal. The bed (see section $8, \mathrm{Pl}$. XXII) is 38 inches thick and lies between beds of shale. It is cut by several small faults which displace the beds from 6 inches to 2 feet. At the time of examination no coal was being produced, though preparations had been made to mine a few tons daily.

Brown Bear mine (location 9).-The Brown Bear mine consists of a horizontal rock tunnel 325 feet long from the surface to the coal bed and two horizontal entries, one to the north and the other to the south, following the bed. The plan of this mine is presented in Plate 
XXII. Stopes are worked above the entries and the coal is taken down through chutes into the mine cars. The Brown Bear, which is the chief producing mine in the field, has an output of a few tons a day during busy seasons in the fall and spring. Sections of the bed at opposite ends of the mine are as follows:

Sections of coal bed in Brown Bear mine.

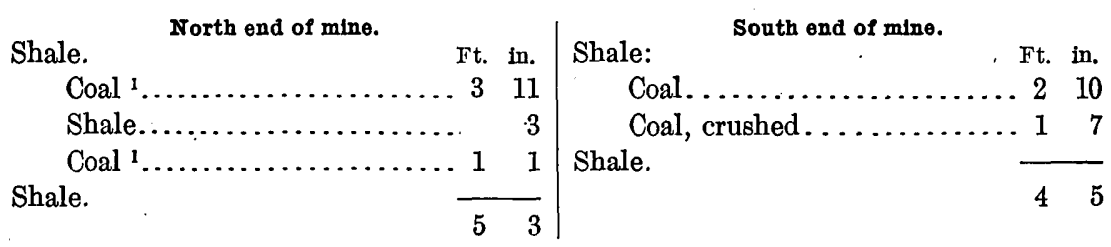

Location 10.-At location 10 a bed of coal represented by section 10 , Plate XXII, is exposed in a surface opening. This is believed to be the bed worked at the Brown Bear mine and is without doubt the one worked at the Horseshoe mine.

Locations 11 and 12.-At location 11 there is an abandoned entry 50 feet long and at location 12 a surface opening on the same bed. A section on this bed is as follows:

Section of coal bed at location 11.

Sandstone.

Ft. in.

Shale, carbonaceous. 2

Shale.

Coal.

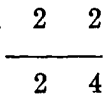

Location 13.-The Horseshoe (abandoned) mine (location 13, Pl. XXII) consisted of a single entry 500 feet long extending north from the side of a steep hill where the bed was exposed. Though badly caved, the mine can be entered for a distance of 200 feet. At that point the following section, shown graphically in Plate XXII, is exposed:

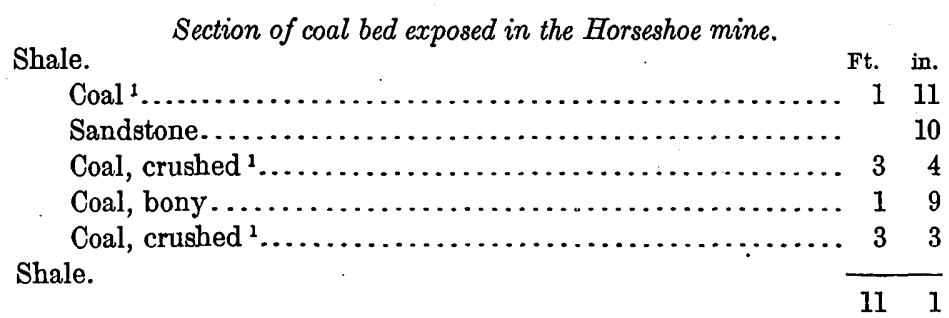

Location 14.-At location 14 there is a small prospect in some slump material which contains fragments of coal.

Location 15.-The extent of the coal encountered in the two prospects at location 15 was not determined, because the openings are

1 A sample of these benches was analyzed with the results shown in the table on p. 385 . 
now caved and the coal is concealed. The size of the dumps indicates that considerable work has been done and some coal taken out. It is reported that the bed is thin, and the fact that this work was abandoned for locations farther from market and where the stratigraphic conditions were less favorable indicates that the prospect was not promising. This prospect lies in a valley with lava-covered hills to the north and débris-strewn hills to the south. About onehalf mile east of the prospects lava caps the hills to the south also and forms the mountain slope on both sides of the creek. The exposed area of coal-bearing rocks is therefore small and confined to the valley of Horseshoe Creek.

\section{CONCLUSIONS.}

The Horseshoe district contains beds of excellent coal thick enough to be mined profitably if they were horizontal, but the steep dip of the beds and the numerous faults render mining expensive, difficult, and uncertain. The beds are irregular in thickness and extent. One of them most probably extends throughout the district, but others are certainly less extensive. Timber and water are abundant, especially water, the supply of which far exceeds the requirements for mining. The district is situated in a region where there is considerable local demand for coal for domestic fuel that now is supplied from mines at a distance. From the data obtained the writer concludes that this district can profitably supply a domestic trade for a long time, but that it can not be reckoned as a factor in the great coal trade of the Rocky Mountain region. 


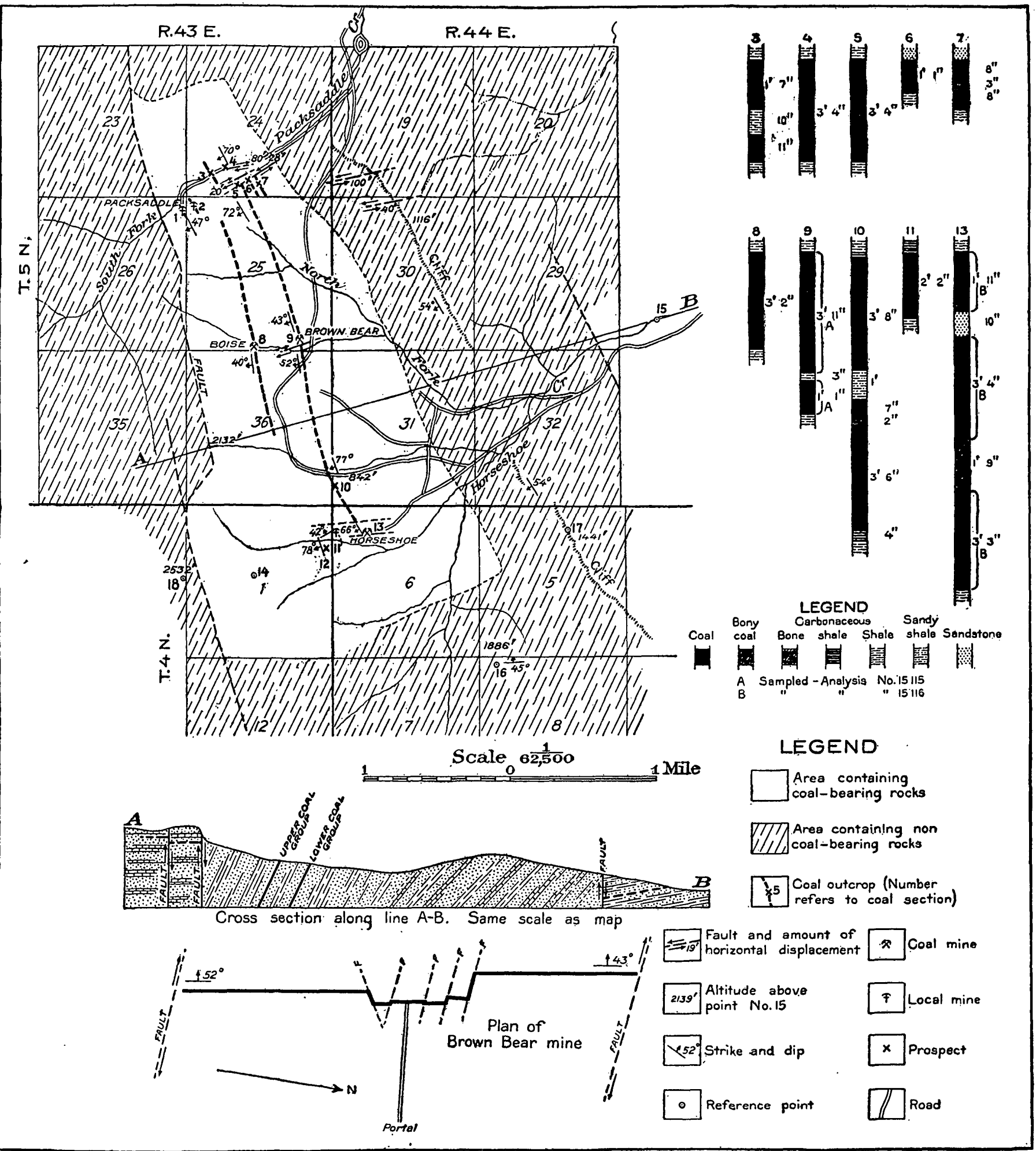

MAP AND SECTIONS OF THE HORSESHOE CREEK DISTRICT OF THE TETON BASIN COAL FIELD, FREMONT COUNTY, IDAHO, AND PLAN OF BROWN BEAR MINE.

By E. G. Woodruff. 


\section{THE GLACIER COAL FIELD, WHATCOM COUNTY, WASHINGTON.}

By E. G. WoodruFr.

\section{INTRODUCTION.}

The Glacier coal. field of Whatcom County is not a producing field 'but has attracted considerable attention because it contains anthracite in at least one place and thin beds of bituminous coal in several other places. The information upon which this report is based was

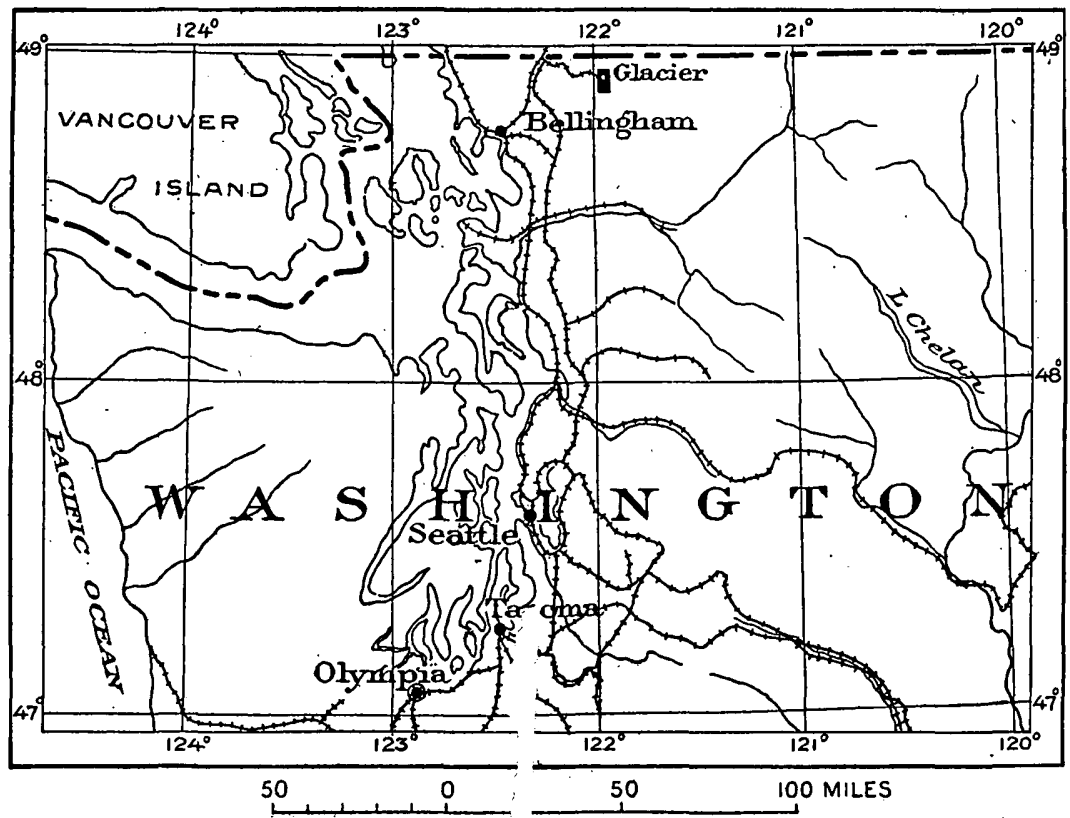

Figure 13.-Map showing location of $t$, Glacier coal fleld, Whatcom County, Wash.

obtained by the writer in the fall of 1912 , but the data for the map (Pl. XXIII, p. 398) were supplied chiefly by Prof. Henry Landes, director of the State Geological Survey of Washington, who also advised the writer concerning the geology of the area and the field methods best adapted to the work.

The Glacier coal field lies in the north-central part of Whatcom County, Wash., in the vicinity of the village of Glacier, which is the terminus of the Bellingham Bay \& British Columbia Railroad. (See fig. 13.) The coal-bearing rocks are reported to extend westward 
from Glacier toward Bellingham Bay, but it was not practicable to extend the present survey in that direction as far as the boundary of the field; consequently the report was not verified. The area considered here embraces about 25 square miles in the western part of T. 39 N., R. 7 E., Willamette base and meridian, and sec. 24 of the township to the west and sec. 31 of the township to the north.

\section{SURFACE FEATURES.}

The Glacier coal field lies on the west face of the Cascade Range, where the slope rises at the rate of nearly 1,000 feet to the mile. The lowest point in the field is on North Fork of Nooksak River near the northwest corner of the field, at an altitude of about 900 feet, and the highest point is on the southern border at an altitude of about 5,000 feet. In the part of the field described in this paper the difference in altitude is about 4,000 feet. The only level ground is the narrow, bowlder-strewn valleys of Nooksak River and Glacier Creek; elsewhere the slopes are steep and cliffs are not uncommon. The mountain sides are so steep and uneven that they can be traversed only on foot or with pack animals along a few trails.

The area is drained by North Fork of Nooksak River, which crosses the northern edge, and by Glacier Creek, which enters near the southeast corner, follows the east side for a distance of 4 miles, then turns northwest to its junction with the main stream near the village of Glacier. Normally these streams are perennial and contain a moderate quantity of swiftly flowing, clear, cold water, but at times of freshet they become torrents. Numerous brooks rise high on the mountain slopes and flow in steep-sided valleys and over cascades at short intervals.

Except where the timber has been cut the mountain slopes are covered by a thick growth of splendid trees, some of which are as much as 5 feet in diameter and 250 feet high. These trees are so large and have grown so closely together that the traveler can seldom see more than a few hundred feet. The ground is covered by vegetable matter composed of fallen twigs, cones, and needles from the trees, and fragments of underbrush.

\section{GEOLOGY.}

\section{GENERAI CONDITIONS IN THE AREA.}

The dense forests which cover most of the field, together with the thick layer of vegetable mold, render geologic examination difficult. The problem is additionally complicated by the prevalence of landslides, which constitute a large part of the surface débris. These slides are not, as is sometimes popularly supposed, masses of rocks which have been loosened from the mountain side and precipitated into the valley below, but they are large masses of rock which bave 
móved slowly and are now at rest or are very slowly moving down the mountain side. In some of these slides the rocks have been broken up and the fragments intermingled, whereas in others the mass has moved as a unit and in many places it is impossible to tell whether the rocks in an outcrop are in place or not.

A satisfactory study of the geology of the field is impossible on account of the dense forests, thick vegetable mold, and rock débris concealing the beds, except on the steep slopes and along the stream channels; hence conclusions must rest mainly on inference.

\section{STRATIGRAPHY..}

During the examination here described no new stratigraphic information was obtained. Smith and Calkins, in 1901, made a reconnaissance across the Cascade Range and published the earliest report ${ }^{1}$ on this general region. A good collection of Eocene fossils had been obtained at Keese, about 8 miles down the river from Glacier, and they therefore referred the strata in that locality to the Eocene. They state that the strata on the river a few miles above Glacier do not resemble the Eocene rocks lithologically, but are very similar to the Cretaceous strata to the west, and on these grounds they doubtfully referred them to the Mesozoic. They collected no fossils in the immediate vicinity of Glacier, but have stated to the writer that the coal-bearing strata closely resemble the Eocene beds farther down the river. Landes, ${ }^{2}$ however, states that Upper and Lower Cretaceous fossils were found on the Mount Baker trail at a point about 4 miles southeast of Glacier. This place is about a mile east of the coal field and directly on the strike, so that unless a fault intervenes the coal-bearing strata would seem to be Cretaceous. If they are Cretaceous, however, the Glacier field is the only one known in Washington in which the coal is older than Eocene, and furthermore it is reported that the coal-bearing rocks extend from Glacier southwestward, probably at least as far as the area in which the rocks are definitely known to be Eocene. Finally, despite the presence of Cretaceous fossils a short distance from the coal field, the lithologic resemblance between the actual coal-bearing strata and the beds known to be Eocene must also be considered. Owing to the complexity of the geologic structure in this area and to the probability of faulting, it is impossible definitely to assign the coalbearing rocks either to the Eocene or to the Cretaceous, although the evidence seems to indicate that they are Eocene.

The coal-bearing rocks are sandstone and shale, which rest on crystalline igneous rocks or schists. The sandstone is by far the

1 Smith, G. O., and Calkins, F. C., A geological reconnaissance across the Cascade Range near the fortyninth parallel: U. S. Geol. Survey Bull. 235, 1904.

2 Landes, Henry, Notes on the Glacier coal field: Pacific Min. Jour., vol. 2, No. 4, p. 61, 1913. 
most abundant. A few measurements made by the writer in the coal-bearing portion of the formations showed about 90 per cent of the strata to be composed of sandstone and 10 per cent of shale. These measurements, however, were not extensive and possibly did not encompass representative sections of the strata. Prof. Landes has done considerable work in the region and estimates the shale to comprise about 60 per cent and the sandstone 40 per cent of the different formations. The sandstone occurs in massive beds, which are separated from one another by thinner beds of shale containing coal at some places. This relation of thick beds of sandstone and thinner beds of shale has had an important bearing on the metamorphism of the coal and the deformation of the bed as explained on a later page. The shale is generally very sandy, but some of it has evidently been derived from fine silt intermingled with vegetable débris and is therefore very carbonaceous and consequently brown or black. At some places the black shale has been mistaken for coal or "coal blossom" or "leads" and the bed prospected. In fact, many of the prospects in the field have followed these so-called coal leads, but have found no coal.

\section{STRUCTURE.}

The field lies on the north flank of the mountain ridge which extends westward from Mount Baker. The general dip of the beds is northwest in the eastern part of the field but is slightly east of north in the western part. The dip is steep, being about $45^{\circ}$, except on the extreme west edge of the field, and locally is as much as $68^{\circ}$. Measurements at different places are shown in Plate XXIII. No faults or local folds were worked out, but undoubtedly some exist, though probably none are very extensive. The coal-bearing strata are so concealed that it is impossible to determine the details of structure, but the discordance in the dip and strike in secs. 18, 19, and 20 points to the conclusion that the beds are probably faulted at several places. Unquestionably, however, great movements of the strata have taken place in the region, and there has been profound folding and faulting. These disturbances were not produced by a sudden heaving, twisting, and breaking of the strata, but by movements continued through a considerable time, during which the coal beds were squeezed and distorted and the coal transformed from low to high grade.

\section{THE COAL。}

\section{GENERAL CHARACTER OF THE BEDS.}

The field contains a large number of thin beds of coal that is mostly dirty, though locally free from impurities. During the movements of the strata discussed above the coal beds have been pinched out at some places and forced into abnormal shapes at others, and the coal 
has been fractured or crushed. In fact, at some places the beds seem to have been subjected to a kind of kneading action, as indicated by the directions of the slickensiding. This variety in direction of movement is shown at Discovery tunnel, where on a few square feet of exposed surface the slickensides are horizontal in some layers, inclined $70^{\circ}$ from the horizontal in other layers, and $30^{\circ}$ in the opposite direction in others. Within a space of a few square yards almost every direction is indicated by the striæ in the coal or shale. The effects of the compression seem to have been concentrated or accentuated in the more plastic shale and coal because they are soft and yielding and comprise a minor part of the strata. As a result of the preponderance of sandstone, as determined by the writer, the shale and coal beds have been forced to conform to new spaces between the more resistant beds because the shale and coal are softer than the inclosing rocks, and consequently the coal has been squeezed into pockets, some of which have considerable thickness but small extent, whereas at other places the beds are pinched and broken.

\section{CHARACTER OF THE COAL.}

The coal of this field ranges in quality from subbituminous to anthracite. At a few places there are thin seams of subbituminous coal and at others beds of bituminous coal and anthracite, but both the low and high grades are not found in the same strata. Only the bituminous and anthracite are abundant enough to be considered. Complete chemical analyses have not been made because unweathered material could not be obtained, but from physical appearance the coal at the Discovery and No. 2 tunnels is a good grade of anthracite. Elsewhere in the field, however, it is bituminous, generally impure, and almost everywhere badly crushed and slickensided. Selected specimens are reported to compare favorably with the best grade of Pennsylvania anthracite, but it is the opinion of the writer that a representative sample of any bed will fall considerably below that standard in calorific value, because the amount of impurities is greater than in Pennsylvania anthracite. Three partial analyses with a field chemical testing outfit showed the ash to be 35 per cent in one sample, 54 per cent in another, and 74 per cent in another. The strata are saturated with water, which has prevented atmospheric weathering from extending to any considerable depth.

As the coal differs from place to place, further details of its character are presented under the description of the prospects.

PROSPECTS.

Considerable prospecting and some fairly deep exploration work have been done in the field, but as previously explained the surface in many places is composed of slide material which covers and con- 
ceals the rocks in place. This disturbed condition of the surface causes prospecting to be uncertain. Some of the tunnels have been started in regularly bedded rocks, which were erroneously thought to be in place, and have terminated in zones of broken rock at the bottom of the slide or entered entirely different strata, over which the prospected beds are found to have slid. Some of these unbroken masses include coal beds which seem to the superficial observer to be in place, but prospecting shows that the bed terminates a short distance below the surface. This condition has led to the unsuccessful ending of several prospect tunnels. In considering this field it should be borne in mind that drill holes or even prospect tunnels can not determine the coal resources, because the beds are so irregular that a test at one place does not indicate the conditions that may be found a short distance away.

As a result of the steep dip of the strata prospects have been opened to follow the beds, which are highly inclined from the horizontal, as in most metalliferous veins. Entries have been driven along the beds and stopes opened or crosscuts dug at promising points.

The following detailed description of prospects begins with those in the northeast corner of the field and proceeds southward by tiers of sections, each tier being considered from east to west. The location of each prospect is shown by the corresponding number on Plate XXIII (p. 398).

Hurst prospect.-The Hurst prospect (location 1), in the southeastern part of sec. 31, T. 40 N., R. 7 E., is about a mile from Glacier. It consists of a prospect rock tunnel 200 feet long and a slope 75 feet deep, which starts in a coal bed about midway of the tunnel. It is possible that the tunnel penetrates only an unbroken rock slide and terminates in country rock at the back. At any rate, the tunnel ends in non coal-bearing rock. A possible explanation for this condition is that the coal-bearing strata are cut off by a fault. The coal bed lies between two thick-bedded sandstones dipping $35^{\circ} \mathrm{N}$. It is extremely irregular, occurring in small lenses, the largest being 6 inches in greatest thickness and 10 feet in length. The bed followed by the slope consists mainly of shale, but contains some coal. The coal is bituminous. At the time of examination no work was in progress, and apparently the prospect had been abandoned.

Hinton prospect.-The Hinton prospect (location 2), in the NW. $\frac{1}{4}$ sec. 6 , T. 39 N., R. 7 E., comprises a tunnel 250 feet long, entirely in thick-bedded sandstone, except through about 8 feet of its length, which is in soft slickensided shale. This shale contains a lens of bituminous coal 4 inches thick and less than 10 feet long. The bed dips $45^{\circ} \mathrm{N}$., and strikes $\mathrm{N}$. $75^{\circ} \mathrm{E}$. At the time of examination this tunnel was abandoned. 
Location 3.-At location 3 there is a tunnel which penetrates surface débris to a depth of 125 feet and terminates in a distorted bed of slickensided shale and bituminous coal 5 feet 2 inches thick. The bed is so much distorted that its normal condition can not be fairly inferred. A most liberal interpretation of the indications of coal, however, points to the conclusion that the bed is valueless.

Armstrong prospect.-The Armstrong prospect (location 4) consists of a tunnel penetrating loose débris to a depth of 75 feet and terminating in a bed of carbonaceous shale 2 feet thick. No coal was found.

Brooks prospect.-At the Brooks prospect (location 5) there is an entry 125 feet long on a coal bed between beds of sandstone which dip $45^{\circ} \mathrm{S}$. The following section is exposed at the end of the entry:

Section of beds exposed at the end of Brooks entry.

Top, sandstone.
$\begin{aligned} & \text { Shale, carbonaceous, badly crushed } \ldots \ldots \ldots \ldots \ldots \ldots \ldots \ldots \ldots \ldots \ldots \\ & \text { Coal, badly crushed. } \ldots \ldots \ldots \ldots \ldots \ldots \ldots \ldots \ldots \ldots \ldots \ldots\end{aligned}$
Sandstone, thick bedded.

The coal appears to be of good quality, but contains impurities disseminated through it. A determination with the field-testing outfit showed 54 per cent of ash. If the coal in this bed were good and the bed easily accessible, or if the bed were moderately impure and the impurities associated with the coal in such a way that they could be washed out, the bed mignt be mined, but as such conditions do not exist, and as the coal is in pockets; it is believed that systematic and economic mining can not be carried on.

Powers prospect.--The Powers prospect (location 6) consists of an entry 115 long in strata that dip $65^{\circ} \mathrm{N}$. The prospect presents an excellent sample of the pockety character of beds and the crushed condition of the coal in this field. At one place in the entry the bed reaches a maximum thickness of 23 inches, but 2 feet from that point it is 17 inches thick, and 5 feet away only 13 inches. Thus, in a distance of 7 feet, the bed has decreased from 23 inches to 13 inches. The coal is very much crushed and slickensided, and contains 35 per cent of ash, some of which is not intimately mixed with the coal. Probably the coal could be improved to a marketable grade by washing if the bed were thick enough and continuous enough to be mined.

Location 7.-At location 7 there is a tunnel 250 feet long, in which an 18-inch bed of shale, containing some crushed coal, is exposed.

Location 8.-At location 8, on the opposite side of the creek and a little to the south from location 7, a tunnel 125 feet long exposes a bed of crushed coal 20 feet long with a maximum thickness of 6 inches. The coal lies between thick beds of sandstone. 
Location 9.-A test hole was sunk with a diamond drill at location 9 to a depth of 500 feet. It is reported that no coal was found. The drill, which was vertical, formed an angle of $25^{\circ}$ with the bedding planes and thus went diagonally instead of directly through the strata. Consequently the hole, although drilled to a depth of 500 feet, tested only a little more than 200 feet of strata.

Location 10.-At location 10, near the middle of the north line of the NW. $\frac{1}{4}$ sec. 20 , a tunnel runs S. $20^{\circ} \mathrm{W}$. for a little more than 150 feet and then southeast 100 feet. In this tunnel are exposed two lenses of black carbonaceous shales and one bed of carbonaceous shale in which there is a seam of crushed lignite 2 inches thick.

Location 11.-At location 11 a tunnel 50 feet long has been driven chiefly in sandstone. A few feet from the portal a 4-inch seam of highly carbonaceous shale has been altered locally to an impure graphite. About 100 feet southwest from the portal of the tunnel in the bottom of the valley, a small prospect in lower strata contains a very irregular pocket of crushed bituminous coal less than 3 feet in greatest thickness. Elsewhere along the outcrop of this bed the maximum thickness was found to be 3 inches, but the coal bed appeared to have been squeezed below its normal thickness.

Location 12.- The following section of strata is exposed at location 12:

Section of strata exposed in the SE. $\frac{1}{4}$ sec. 19.

Top, sandstone, gray, massive; contains impressions of plants. Ft. in.

Shale, carbonaceous, slickensided......................... 12

Sandstone, black, shaly; contains impressions of plants; greatest

thickness.................................. 1

210

Location 13.-An entry has been dug to a depth of 45 feet at location 13. In this prospect a bed of crushed carbonaceous shale contains seams of coal. The thickness of the shale bed is very irregular. It is thin near the portal, increases to 36 inches at a depth of 30 feet, decreases to 14 inches 9 feet from that place, and is absent at the end of the entry. The thickest seam of coal in the bed has a maximum thickness of 4 inches, but even that appears to be in a pocket. The coal is bituminous.

Location 14.-At location 14, in sec. 19, a tunnel 40 feet long cuts the edge of a lenticular pocket of coal. A cross section of the tunnel is a broad oval in outline, about 6 feet high and 4 feet broad. The coal bed cuts diagonally across the face of the tunnel. Near the floor the coal seam is less than 1 inch thick, but it increases to 8 inches at the top of the tunnel. In a distance of a little more than 6 feet the bed changes from 6 inches in thickness to 1 inch. The coal, which lies between beds of massive sandstone that are much 
more resistant than the coal, is badly slickensided and appears to have been squeezed into its present form. A partial analysis of the coal showed it to contain 74 per cent of ash.

Hinton's prospect.-The Hinton prospect (location 15) consists of two entries, one 50 feet above the other, on a bed of coal lying between thick beds of sandstone which dip $56^{\circ}$. The lower entry is 15 feet long and contains a stringer of slickensided coal which ranges from a feather edge to 6 inches thick. The upper prospect is 50 feet long and contains crushed shale but no coal.

Bellingham Bay \& British Columbia mine.-The Bellingham Bay $\&$ British Columbia mine (location 16), is reported to have been extended more than 1,000 feet along the strike of a coal bed before it was abandoned, but only the first 150 feet was examined by the writer. At the portal the following section is exposed:

Section of strata exposed at the portal of the Bellingham Bay \& British Columbia tunnel.

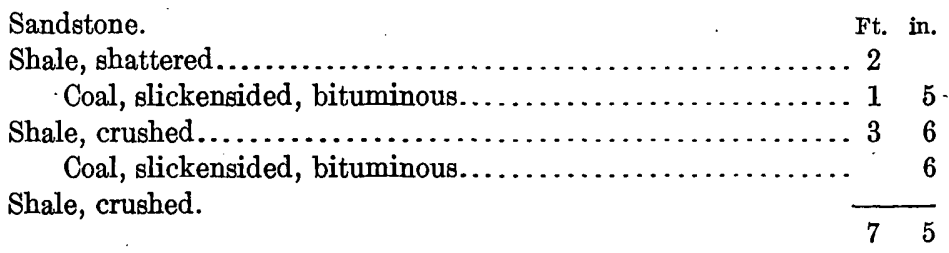

At two other places carefully examined, namely, 50 feet and 150 feet from the portal, no coal was found. On the mountain side, about 100 feet above the portal, the bed is thinner; 200 feet above the portal its thickness is still more diminished; and a little higher up it has disappeared. Evidently the bed consists of a small lens or pocket. This coal is fairly good. A partial analysis gave 5.3 per cent ash.

Tunnel No. 2.-Tunnel No. 2 (location 17) is reported to be 700 feet long. The writer examined the first 325 feet, which is believed to fairly represent the whole entry. In that distance the beds are crushed, slickensided, distorted, and locally metamorphosed. The thickness of the bed differs so that measurements do not represent conditions 100 feet away. At a point 325 feet from the portal the coal appears to lie in a pocket 3 feet thick, containing bright anthracite in the upper part and finely crushed bituminous coal in the lower part. Because the strata are badly disturbed no good dip measurement could be obtained, but a fairly reliable reading gave $69^{\circ}$. At the time of the examination the entry was deserted and workmen were starting a new one a short distance to the west but had not passed through the thick surface débris.

Discovery tunnel.-Discovery tunnel (location 18), reported to be between 750 and 780 feet long, is the most promising prospect in the field. At the time of examination the tunnel was closed and was 
filled with inflammable gas. It is said that the following section is exposed at the end of the tunnel:

Section of coal bed reported to be exposed in Discovery tunnel.

\begin{tabular}{|c|c|}
\hline Slate. & \\
\hline Coal. & 2 \\
\hline Bone. & 1 \\
\hline Coal. & 6 \\
\hline
\end{tabular}

Along the outcrop, about 100 feet from the tunnel, the bed is thinner than in the tunnel, but in the short distance that it is exposed it seems to. increase abruptly downward, indicating that the tunnel enters a pocket. The coal, which is anthracite, is badly crushed and slickensided and in general breaks into small, irregular lumps. It is estimated that more than 50 per cent of the coal is crushed into pieces less than 1 inch by 3 inches. Some pieces are 6 or 8 inches in diameter and a few are as much as 1 foot. It is believed that this tunnel enters an exceptionally thick lens of coal, but it is inferred that the lens is not extensive, because 100 feet above the tunnel it is thinner than it is reported to be in the tunnel and it seems to decrease in thickness upward. This conclusion is strengthened by the fact that there is only a little coal in the Smith tunnel a mile west at the same stratigraphic horizon.

Smith tunnel.-The Smith tunnel (location 19) is about 300 feet long in rocks which are so badly disturbed that a fair estimate of the amount of coal can not be made. The coal is found in a distorted bed of shale which ranges from 4 feet to a feather edge within a horizontal distance of 100 feet and in general is less than 6 inches thick.

\section{CONCLUSIONS.}

The field has been prospected extensively but contains no mine except Discovery No. 2 and the Bellingham Bay \& British Columbia mine, abandoned some years ago. The beds have been tested by prospects at various stratigraphic horizons, especially in the lower part of the sedimentary rocks, which seem to contain the most coal. These prospects have shown that the coal occurs in pockets that differ greatly in size. The largest pocket found is at Discovery tunnel No. 1, but it is probable that even larger ones may be found. The coal is mostly anthracite or high-grade bituminous, but some of it is lower grade. Generally the percentage of ash in the coal is very high, especially when the whole of the bed is considered. From the data obtained the writer concludes that the field contains coal in pockets, sume of which are large enough to furnish a small supply of fuel, but as yet the prospecting has not developed coal enough to warrant the expectation that the field will produce coal in commercial quantities. 


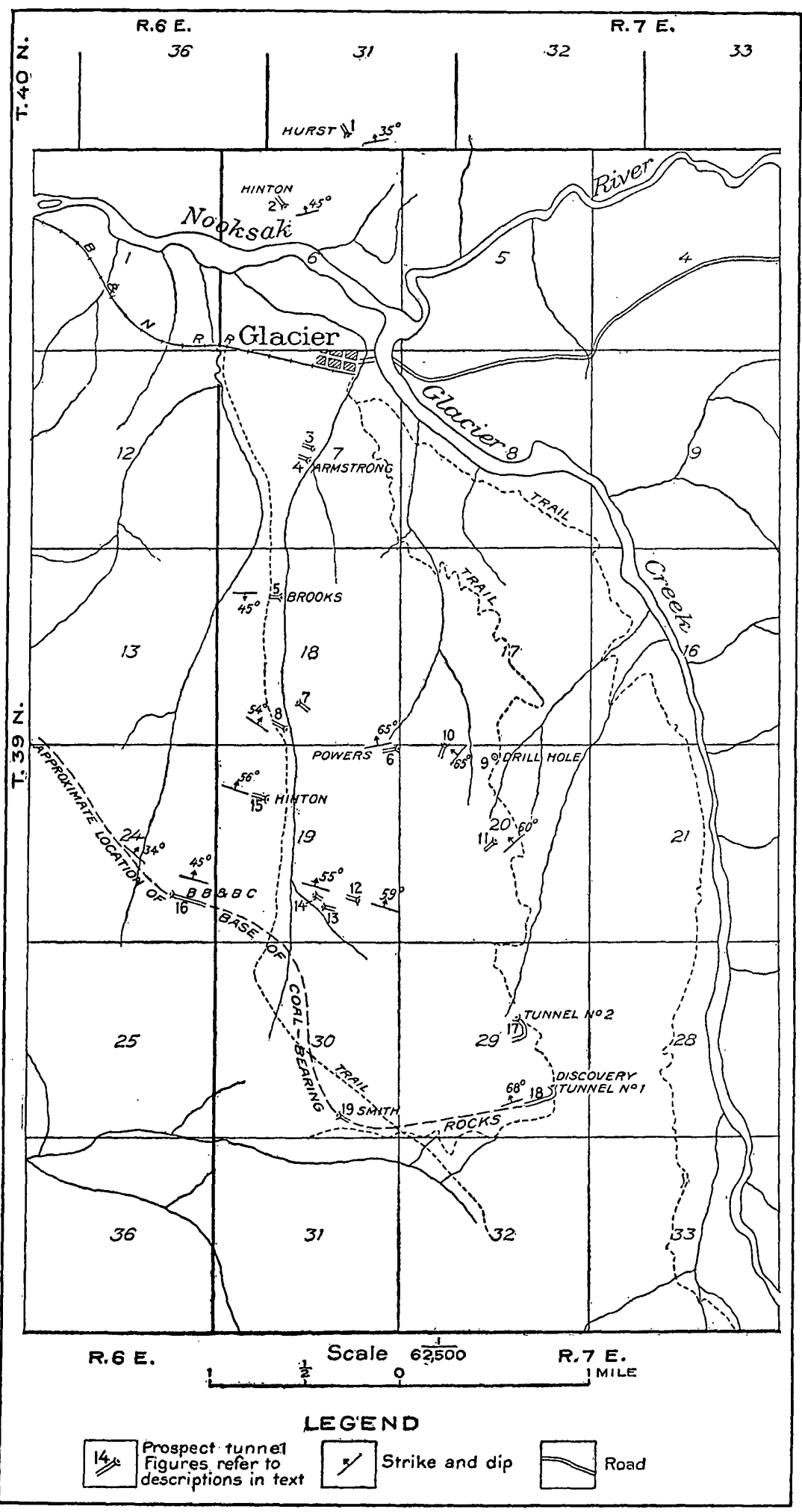

MAP OF THE GLACIER COAL FIELD, WHATCOM COUNTY, WASH.

By E. G. Woodruff. 


\title{
THE EDEN RIDGE COAL FIELD, COOS COUNTY, OREGON.
}

\author{
By C. E. Lesher.
}

\section{INTRODUCTION.}

It has long been known that Eden Ridge, Oreg., is underlain by coal, and a large amount of prospecting has been done on the ridge and more recently in the Squaw Basin, immediately to the south. The beds first discovered are so bony that their ultimate workability has been questioned and considerable litigation has resulted because of their doubtful value. Furthermore, owing to the fact that the Eden Ridge coal occurs in the same formation as that of the neighboring and better-known Coos Bay field, which is subbituminous in grade, the United States Geological Survey and others have incorrectly assumed that the Eden Ridge coal is also subbituminous and that, being thus of low grade and also bony in character, it is probably of little value. In 1912 M. R. Campbell, of the Geological Survey, made a brief examination of the coal and his work showed that, contrary to the previous assumption, it is bituminous in grade. In view, however, of the recent extension of prospecting and the discovery of less bony coal beds in the Squaw Basin district, the writer made the examination here described. This work was detailed in character and was undertaken for the purpose of ascertaining the extent and character of the field and of classifying the land as coal or noncoal. The field work has not been completed, but the results obtained are published in this preliminary report partly in order to aid in the prospecting now in progress and partly because of the interest attaching to this field as the only area, so far as known, of bituminous coal of commercial importance in Oregon.

The field lies wholly within the Siskiyou National Forest. It is 35 miles west of the station of West Fork (Dothan post office), on the Southern Pacific Railroad, and 35 miles south of the terminus of the Coos Bay, Roseburg \& Eastern Railroad at Myrtle Point. The field is not easily accessible at the present time, travel from these railroad points being confined to saddle horses and pack trains. Figure 14 shows the geographic position and known extent of the field.

The Eden Ridge field is comparatively free from complicated structure, and the field work consisted principally in determining the areal 
distribution and stratigraphic position of the various coal beds. Because of the dense underbrush and heavy timber locations could be made only by compass traverse, either paced or measured with tape, and tied to established land corners. Altitudes were determined with the aneroid barometer. In the unsurveyed portion of the field corners established by private surveys were used for horizontal control: Every prospect was visited and the section of the coal bed measured; 26 prospects were sampled. Twenty-six float and sink tests and 80 ash determinations were made in the field with

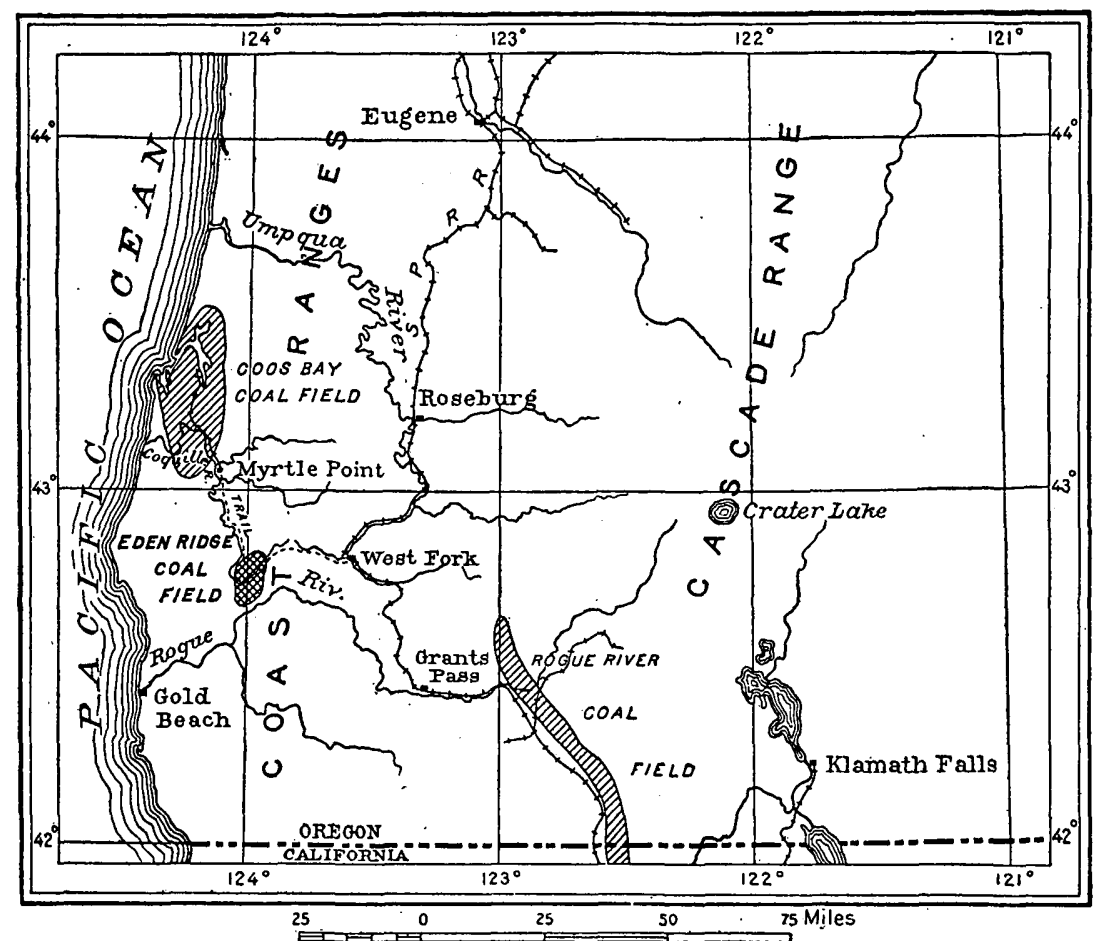

FIGURE 14.-Map of southwestern Oregon, showing location of the Eden Ridge and neighboring coal fields.

a portable analytical outfit. Five samples were taken for check analysis by the Bureau of Mines.

The field examination on which- this report is based occupied six weeks during the summer of 1913. Assistance in the field was rendered by $M$. J. Anderson throughout the examination and by Harry Hillis for a week at the end of the season. The writer wishes to acknowledge his indebtedness to W. B. Meyers, Timothy Billings, Lee Emerson, and others for aid and many courtesies during the field work, and to M. R. Campbell and G. H. Ashley, of the United States Geological Survey, for advice and counsel in preparing the data. 


\section{SURFACE FEATURES.}

The Eden Ridge field is characterized by a very uneven surface. Eden Ridge, Squaw Basin, and the area between Ash Swamp and the Bluff constitute three distinct topographic units, all drained by South Fork of Coquille River. (See Pl. XXIV; p. 404.)

Eden Ridge has a general northeast-southwest direction. Its highest point, about 3,500 feet above sea level, is 1,300 feet above the river at the mouth of Bear Creek on the east and 2,900 feet above the river at the mouth of Delta Creek on the west. The slopes of the ridge are very steep and are incised by the sharp canyons of the smaller streams. At the southern end of the ridge a vertical sandstone cliff 100 feet high and half a mile long is known as the "Big Slide," as it is the result of comparatively recent slumping. Another prominent escarpment, known as the "Bluff," is 150 to 200 feet high and extends from Forty Foot Falls on South Fork of Coquille River eastward to the Rogue River divide. Between Ash Swamp and the "Bluff" the surface has a more or less uniform slope from the same divide to Coquille River. (See Pl. XXIV.) Squaw Basin comprises the area south of the "Bluff" and east of Squaw Creek, extending from Coquille River to the Rogue River divide. Here the topography is rougher and dissection is well advanced; the smaller streams have cut sharp canyons 50 feet to 100 feet deep.

The possibility of developing water power under high head on South Fork has long been recognized. 'The water might be taken from the south side of the ridge near the Billings homestead either by tunnel through the ridge or by flume or high pressure pipe around it to the mouth of Delta Creek on the north side. It is estimated that with the excellent storage facilities offered by Ash Swamp, in which the river might be impounded and the flow of water thus equalized, not less than 7,000 continuous horsepower could be generated.

The area is heavily forested and contains much merchantable timber. The common varieties, named in the order of their value, are Port Orford white cedar, Douglas fir, and hemlock. The quantity of timber is said to range from 50,000 to 200,000 board feet to the acre. Madrona, salal, vine maple, tanbark oak, ferns, chinquapin, and buck brush are common and abundant forms of undergrowth. The climate is that typical of the west slope of the coast ranges, a rainy season lasts from October to June and a comparatively dry season from July to September. The total precipitation in 1912 is reported to have been 112 inches, but this is probably much higher than the yearly average.

$365^{\circ}-$ Bull. $541-14-26$ 


\section{GEOLOGY.}

\section{STRATIGRAPHY.}

\section{ARAGO FORMATION.}

The rocks that outcrop in the Eden Ridge field are conglomerate, coarse yellowish sandstone, dark-colored shale, in part carbonaceous, and coal. They were studied by J. S. Diller in connection with the geologic mapping of the Port Orford quadrangle ${ }^{1}$ which includes the west half of Eden Ridge. According to Diller these rocks, to which he has applied the name Arago formation, are characterized by Eocene marine fossils. The coal-bearing rocks of the Coos Bay field belong to the same formation, but in that field the coal is of lower grade. The Arago lies unconformably on the Myrtle formation, of Lower Cretaceous age, which contains no coal.

Exposures in the Eden Ridge field are insufficient to afford a complete detailed stratigraphic section of the Arago formation. The strata above a blue conglomerate, which is a conspicuous horizon marker, are fairly well exposed on the slopes of the ridge, but relatively little is known of the character of the rocks, which underlie it or of the positions of the coal beds. The following is a generalized section of the rocks above the blue conglomerate:

Generalized section of rocks above the blue conglomerate exposed in the Eden Ridge coal field.

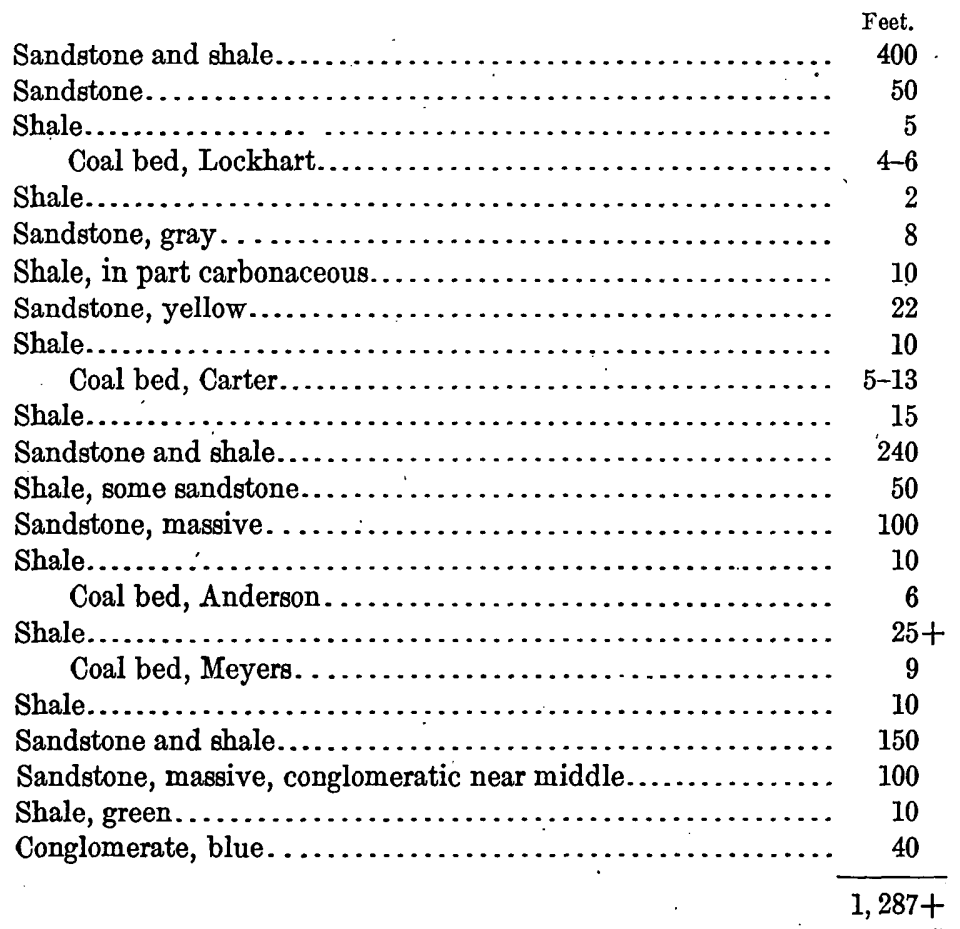

1 Diller, J. S., U. S. Geol. Survey Geol. Atlas, Port Orford folio (No. 89), 1903. 
The above section is compiled from measurements made at several places in the field, and inasmuch as the strata overlying the conglomerate are known to differ in thickness and character the section can not be considered as representing correctly all the strata at any one locality.

The blue conglomerate is the only characteristic horizon marker in the field. It is about 40 feet thick and is composed of small pebbles of altered volcanic rock, chiefly andesitic in character, and fragments of fine-grained quartzites and slates ranging in size from one-eight of an inch to 2 inches in diameter. Outcrops of the conglomerate above water level along the river in the $N$. $\frac{1}{2}$ sec. 33 are light gray, although some fragments are red and others are light green. Wherever it is thoroughly wet, as in stream beds, it has a characteristic bluish color, and for this reason it is here referred to as the blue conglomerate.

\section{STRUCTURE.}

The strata. in this field dip toward a point near its center, thus forming an ellipitcal basin. The longer axis of the basin has a general north-south direction and the shorter axis is at right angles and has a slight pitch to the east. On the west side of the field the dip is $10^{\circ}-$ $17^{\circ} \mathrm{E}$. and on the east side there is a similar dip to the west. The north-south axis of the basin passes through the center of secs. 20, 29, and 32 , T. 32 S., and to the east of Squaw Camp in T. 33 S. On the north side of the field a southerly dip of $5^{\circ}-15^{\circ}$ prevails. Along Squaw Creek in T. $33 \mathrm{~S}$. the rocks dip $12^{\circ}-15^{\circ}$ NE., and in the east half of the Squaw Basin district the dip is to the northwest at slightly greater angles.

Four faults were mapped: The Ash Swamp fault in secs. 22 and 23 has a vertical displacement of 800 feet. South of the fault the blue conglomerate is 800 feet above the river on the slope of Eden Ridge, and north of the fault it is at river level. The Bear Creek fault crosses secs. 31, 32, 33, and 34. At the mouth of Bear Creek in the north half of sec. 33 the displacement is 300 to 400 feet, with downthrow on the south side; in the west half of sec. 31 the displacement is 150 feet, with downthrow on the north side. The fault in sec. 28 has a vertical displacement of 200 feet, with downthrow on the south side. The fault south of sec. 32 , at Little Falls, is of small but undetermined extent. A small fault in the NE. 1 sec. 29 was not mapped.

As shown on the map (Pl. XXIV, p. 404) the outcrop of the blue conglomerate has been greatly displaced by these faults. South of the Bear Creek fault the outcrop of the conglomerate crosses Boulder and Bear creeks, forms the face of the "Bluff," crosses the river at the Forty Foot Falls, and swings around the south end of Eden Ridge. Between the Bear Creek fault and the fault in sec. 28 the conglomerate is exposed on both sides of the river near water level, and north of 
the fault in sec. 28 and on the north side of Eden Ridge it outcrops on the side of the ridge. In the SW. $\frac{1}{4}$ sec. 23 it is brought to river level by the Ash Swamp fault, but northward it rises and forms a rim rock possibly surrounding Ash Swamp.

\section{THE COAL.}

\section{GENERAI CHARACTER.}

The coal in the Eden Ridge field is bituminous in grade, and some of it is believed to possess coking qualities. It does not slack on exposure to the air, and when fairly pure has a heating value of over 11,000 British thermal units.

Three beds, the Lockhart, Carter, and Anderson, are known to underlie Eden Ridge, and the Anderson bed is also found in a portion of the area south of the river. (See map, Pl. XXIV.) The Meyers bed has been found only south. of the ridge, although it may be coextensive with the Anderson bed. In the Squaw Basin district three coal beds outcrop but were not mapped. They are believed to be stratigraphically. lower than the beds on Eden Ridge, but this fact has not been definitely established. If lower than the Anderson bed they underlie all of Eden Ridge, Ash Swamp, and probably a large part of the area between Ash Swamp and the Bluff.

As shown by the graphic sections on Plate $\mathrm{XXV}^{1}$ (p. 408), all these beds are badly broken by shale and bone partings. Moreover, in nearly all the sections measured in the field the bed contains numerous lenses of dirty coal or bone, so that it is impossible to state accurately the thickness and value of the bed in general terms. In the following descriptions 'of the occurrence and distribution of these beds frequent reference will therefore be made to the graphic sections, the character and purity of thecoal being more extendedly discussed afterward.

The Lockhart bed is mainly carbonaceous shale and bone with layers of coal of a maximum thickness of 3 inches. A sample from location 1 of all this bed except the clay partings was analyzed in the field and found to contain 54 per cent of ash. The Squaw Creek beds, on the contrary, are mainly coal, with a few thin layers of bone. The Carter, Anderson, and Meyers beds are intermediate in quality between the Lockhart and Squaw Creek beds. The quality of the Anderson and Carter beds is very much better at the south end of the field than it is at the north end.

\section{DISTRIBUTION.}

The Anderson bed may be readily identified by its position 300 feet stratigraphically above the blue conglomerate and by the presence near its middle of a characteristic white clay parting. (See

${ }_{1}$ All the prospects at which sections were measured are numbered on the map (PI. XXIV), and the sections measured at these points are numbered correspondingly on $\mathrm{Pl}$. XXV and in the text. 


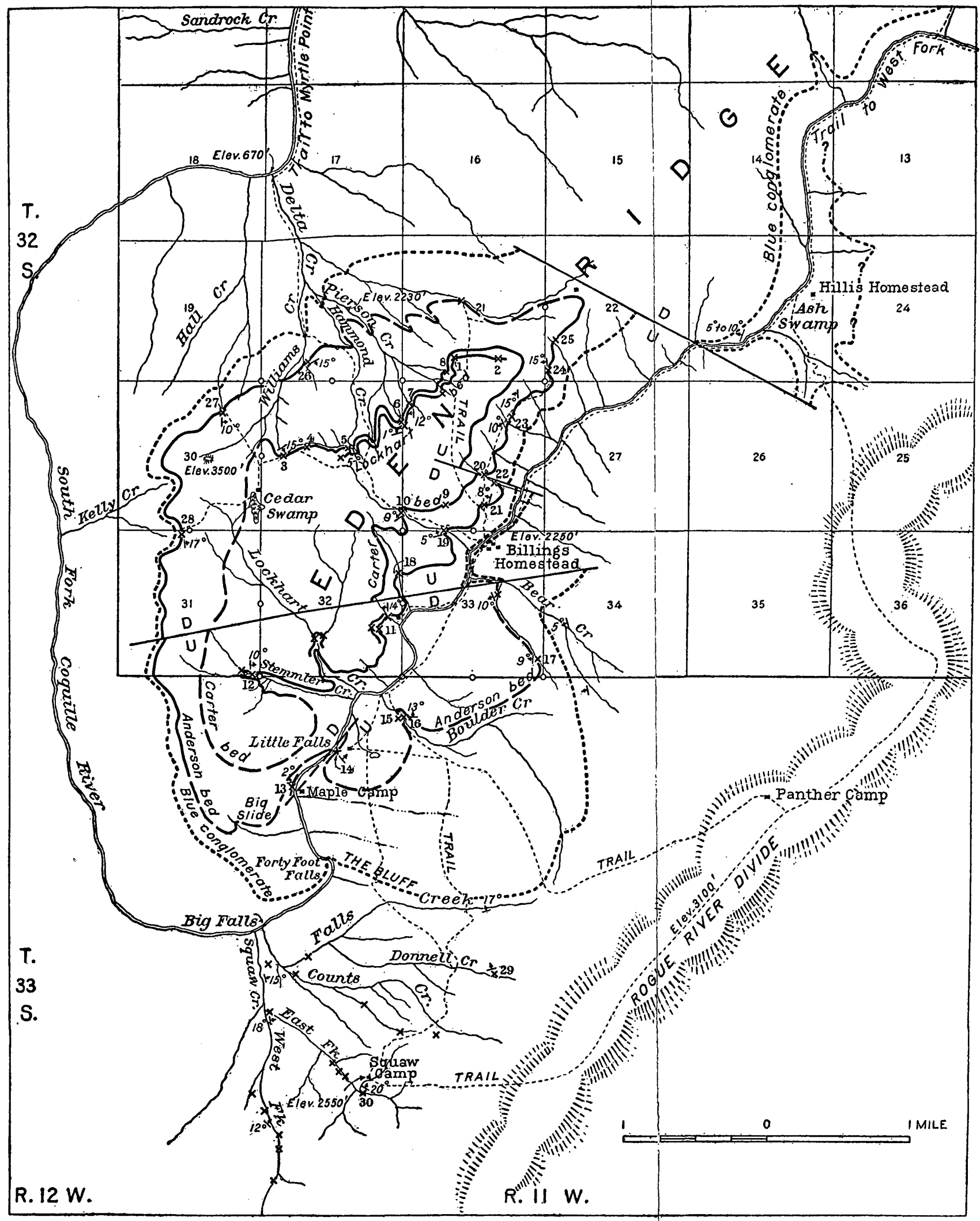

\section{LEGEND}

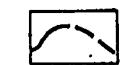

Coal outcrop

Line broken where location is inferred

\section{2}

Coal prospect Number refers to section on Plate XXV

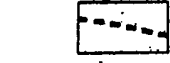

Blue conglomerate

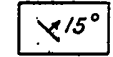

Strike and dip

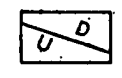

Fault

Showing upthrow (U) and downthrow (D)

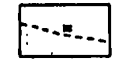

Trail and cabin

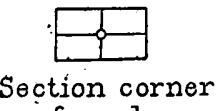
found 
secs. 14 and 15, and 17 to $28, \mathrm{Pl}$ XXV, p. 408.) The outcrop of this bed is clearly marked on the north side of the ridge and on the south side from sec. 22 to the Bear Creek fault. In sec. 21, in the S. $\frac{1}{2}$ sec. 33 , T. 32 S., and in T. 33 S., the location of the outcrop, as shown on Plate XXIV, is only approximate. Prior to the examination by Mr. Campbell in 1912 the Anderson bed had not been found on the north and west sides of the ridge, and it was generally supposed that it was not continuous under Eden Ridge. It now seems certain, however, that the Anderson bed underlies about 5 square miles of Eden Ridge and approximately 1 square mile south of the river adjacent to the ridge.

The Carter bed is 400 feet stratigraphically above the Anderson bed. It has been opened in six places on the north side of the ridge, and the position of its outcrop for a distance of 2 miles is well established. On the south side of the ridge two openings have been made on this bed north of the Bear Creek fault and three south of the fault. Approximately 3 square miles along the crest of Eden Ridge are underlain by the Carter bed. The greatest thickness measured on this bed is about 8 feet, at location 7 , and the smallest is 3 feet 7 inches, at location 12 . Just above the section measured at location 9 (Pl. XXV) there is between 7 and 8 feet of bone and carbonaceous shale with numerous layers of clean coal one-fourth to one-half inch thick. If this material be considered part of the bed, the thickness here is nearly 13 feet. Location 4 is a shallow pit with several feet of water in the bottom, so that the lower part of the section and the total thickness could not be measured.

The Lockhart bed is 50 feet above the Carter. It is exposed in five prospects on the north side of the ridge in secs. 21,28 , and 29 , and in three on the south side in sec. 32 . The bed is everywhere composed of carbonaceous shale and bone with numerous thin layers of clean coal from a fraction of an inch to 3 inches thick. At locations 1 and 2 this bed is about 6 feet thick and it is probable that it is of equal thickness elsewhere. (See secs. 1 and 2, Pl. XXV.) The distinctive character of the bed and its stratigraphic position with reference to the Carter bed render it easily recognizable in the field. The bed has been prospected only in the areas noted above, and its outcrop was not mapped elsewhere, but the bed is believed to be coextensive with the Carter bed.

The Meyers bed has been opened at only two prospects, locations 13 and 16. It is 9 feet thick at location 16. (See sections on $\mathrm{Pl}$. XXV.) Owing to the fact that the coal-bearing shale south of the river is badly slumped, except possibly at these prospects, the exact stratigraphic position of the bed is doubtful. The Anderson bed at location 15 is about 25 feet above the horizon of the Mejers at location 16, but the distance between these beds at locations 13 and 14 
could not be determined, owing to the Little Falls fault. On the other hand coal which may represent the Meyers bed is exposed on Eden Ridge about 50 feet below the Anderson, so that the true distance between these beds may be 50 feet instead of about 25 feet.

In Squaw Basin 18 exposures of coal were observed. Only 2 of them, at locations 29 and 30, had been sufficiently prospected in August, 1913, to permit the determination of the thickness and character of the coal. At these two places the bed is 5 feet and 8 feet thick, respectively, but it is reported that on the Rogue River side of the divide south of Squaw Camp a prospect has recently been opened in which the bed is 13 feet thick. The prospecting is not sufficiently advanced to admit of satisfactory correlations of these exposures, but it is probable that there are at least three beds, the two lowest of which are not over 75 feet apart and the third or uppermost several hundred feet higher. The exact relation of these beds to those on Eden Ridge could not be positively determined. It is certain, however, that, unless there is a fault of greater magnitude than any now known in the area between Big Falls and the outcrop of the blue conglomerate immediately to the north, the Squaw Basin coal beds are 600 to 800 feet stratigraphically lower than the Anderson bed. No surface indications of such a fault have yet been observed, and it is believed that these coal beds are in reality lower than the Anderson bed. If they are lower, they must, if continuous, underlie all of Eden Ridge, Ash Swamp, and the greater part of the area between Ash Swamp and the bluff. The rocks exposed in Squaw Basin outcrop on the south slope of Rogue River divide, and this divide, therefore, marks the approximate limit of the coal field on the south.

\section{QUALITY.}

The coal in the Eden Ridge field is bituminous, and in the Squaw Basin district is believed to have coking qualities. It commonly has a bright luster, though in places it is somewhat dull. There is a poor vertical cleavage, but no pronounced lamination parallel to the bedding. The coal does not slack or disintegrate on exposure to the air, and, though thoroughly wet in many of the outcrops of the field, it does not appear to be readily affected by the weather. These physical properties, together with the low moisture content, averaging 4 per cent, the high heat value, about 12,000 British thermal units for coal with 10 per cent or less ash, and the possible coking quality, warrant the classification of the Eden Ridge coal as bituminous.

\section{LOCAL FEATURES OF COAL BEDS.}

The coal beds in this field (see sections on Pl. XXV) contain material of all grades from clean bituminous coal with ash as low as 10 per cent to bone with 60 per cent ash and carbonaceous shale. The 
lenses of coal, bony coal, and bone ${ }^{1}$ are from a fraction of an inch to several inches in thickness and grade into one another both vertically and horizontally. The gradation from coal through bony coal and bone to carbonaceous shale is in most places almost imperceptible. Although in the graphic sections (Pl. XXV) parts of a bed as much as 3 feet thick are shown as coal, it should be understood that at no place is there so much as 1 foot of coal that does not contain at least a perceptible amount of bone or bony coal. Much of the material can not be accurately classified without a determination of its ash content, and the same portion of the bed may be differently described and classified by different observers. In addition to the difficulty of determining in the field what should be the designation of the different parts of a bed is the difficulty of showing the condition of the bed graphically. For instance, in the middle of the section at location 3 (see Pl. $\mathrm{XXV}$ ) is a layer 1 foot 9 inches thick which is a mixture of carbonaceous shale, bone, and bony coal that can not be differentiated. This has been shown graphically by the symbol of bone superimposed upon that for carbonaceous shale.

So great is the variability of the beds that no two sections of a bed exactly agree, even though measured in the same opening, and the same section measured by different observers may be classified differently. To illustrate this difficulty, several sections measured by M. R. Campbell in the same prospects measured by the writer are given on Plate XXV. For purposes of discussion the sections of the Carter bed at location 7, measured by $\mathrm{Mr}$. Campbell and the writer, may be taken as a typical example. These sections were measured at the face of a prospect drift 110 feèt long at points not over 10 feet apart. Comparison of the sections measurement by measurement indicates that in the upper $5 \frac{1}{2}$ feet, although each section shows approximately the same total number of inches of coal $-45 \frac{1}{2}$ inches and 47 inches, respectively - the coal is differently distributed, and where one section shows three layers of carbonaceous shale the other shows bone. Furthermore, the total thickness of the bed between shale roof and floor in one section is 8 feet $1 \frac{1}{2}$ inches and in the other 6 feet $1 \frac{1}{2}$ inches. Perhaps a more striking example of the irregularity of the beds is derived from a comparison of the sections of the Anderson bed measured by Mr. Campbell and the writer at location 21 . These sections were measured at the face of a prospect drift 103 feet long at points about 5 feet apart. One section shows a total of 45 inches of coal in nine layers which range in thickness from 2 inches to 10 inches; the other has but one stratum of coal, and that is 14

\footnotetext{
1 The material here described as bone is a black compact and coherent mixture of carbonaceous and noncarbonaceous material and is not considered a fuel in the ordinary sense of the term. It contains 33 per cent or more of ash; its luster is dull; its streak is dark brown; its texture is dense; its fracture is even; and it is usually harder and decidedly heavier than the coal with which it is associated. It is generally tough and when struck with a hammer gives a dull impact. "Bony coal" is a coal containing a large percentage (less than 33 ) of ash, either as a coherent mixture or as thin alternating layers of coal and bone.
} 
inches thick. The 10-inch and $5 \frac{1}{2}$-inch layers of coal above the parting in the section measured by Mr. Campbell are represented by 11 inches and $5 \frac{1}{2}$ inches of bony coal in the section measured by the writer. The 11 -inch and $5 \frac{1}{2}$-inch layers of bony coal were sampled separately and found to contain 30 per cent and 29 per cent of ash, respectively.

Under such conditions it is manifestly impossible properly to determine the true character and quality of a coal bed except by making chemical analyses of numerous samples. Accordingly, the beds at all prospects, with the exception of those at locations $2,4,8$, and 24, were sampled for analysis. ${ }^{1}$ Fifteen samples of coal from this field have been analyzed by the Bureau of Mines and the heat value of the coal experimentally determined. Five of these samples were taken by W. M. Stephens, mineral examiner of the Forest Service, five by M. R. Campbell, of the Geological Survey, and five by the writer. Analyses Nos. 9151 and 9187 of two samples taken by M. A. Pishel in the Coos Bay coal field are also given. ${ }^{2}$

On Plate XXV the parts of each bed sampled are bracketed and lettered, and the corresponding analyses in the table (pp. 411-413) are denoted by a combination of the number of the prospect and the letter. showing the part sampled. Thus one sample was taken of the bed at location 6 and its analysis is designated in the table as $6 \mathrm{~A} ;$ No. 22 was sampled in two parts, of which the analyses are represented by $22 \mathrm{~A}$ and 22B; No. 27 was sampled by both the writer and Mr. Campbell and the analyses are numbered $27 \mathrm{~A}$ and $27 \mathrm{~B}$. The sections of the Anderson bed represented by samples $23 \mathrm{~B}$ and $23 \mathrm{C}$ are not shown on Plate XXV but are given below, as are also the sections measured by W. M. Stephens, the corresponding samples being numbered $5 \mathrm{C}, 10 \mathrm{~B}$, 18D, 21B, and 21C (laboratory Nos. 14048, 14049, 14047, 14045, and 14046, respectively).

Sections of Anderson coal bed at location 23, NE. $\frac{1}{4}$ sec. 28, T. 32 S., R. 11 W.

Section measured 20 feet from section 23 shown on Pl. XXV.

Shale.

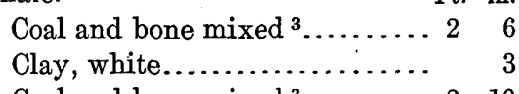
Shale.
Section below white clay parting, measured 5 feet from preceding section.

Clay, white. $\quad$ Ft. in. Coal ${ }^{4} \ldots \ldots \ldots \ldots \ldots \ldots \ldots \ldots . . .6$

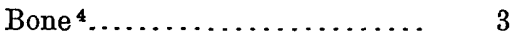

Coal ${ }^{4} \ldots \ldots \ldots \ldots \ldots \ldots \ldots \ldots \ldots$

Shale.

\footnotetext{
1 The samples for analysis were taken according to the standard method of the United States Geological Survey, which briefly is as follows: The face to be sampled is cleaned and squared up and a cut made across that part of the bed to be sampled of such size as to yield about 6 pounds of coal to the foot of thickness of bed, all partings of clay over three-eighths of an inch thick being rejected and the whole sample being caught on a piece of oilcloth. The sample is then reduced in size to pass a screen with openings one-half inch square and cut down by quartering to a final sample of 3 to 4 pounds, which for transmission to the Bureau of Mines is sealed in a galvanized-iron can.

2 Diller, J. S., and Pishel, M. A., Preliminary report on the Coos Bay coal field, Oregon: U. S. Geol. Survey Bull. 431, p. 190, 1911.

${ }^{3}$ Included in sample 23C (float and sink test, p. 417).

4 Included in sample 23B (float and sink test, p.417). A sample of the 9 inches of coal in this section was analyzed separately and found to contain 22 per cent of ash.
} 

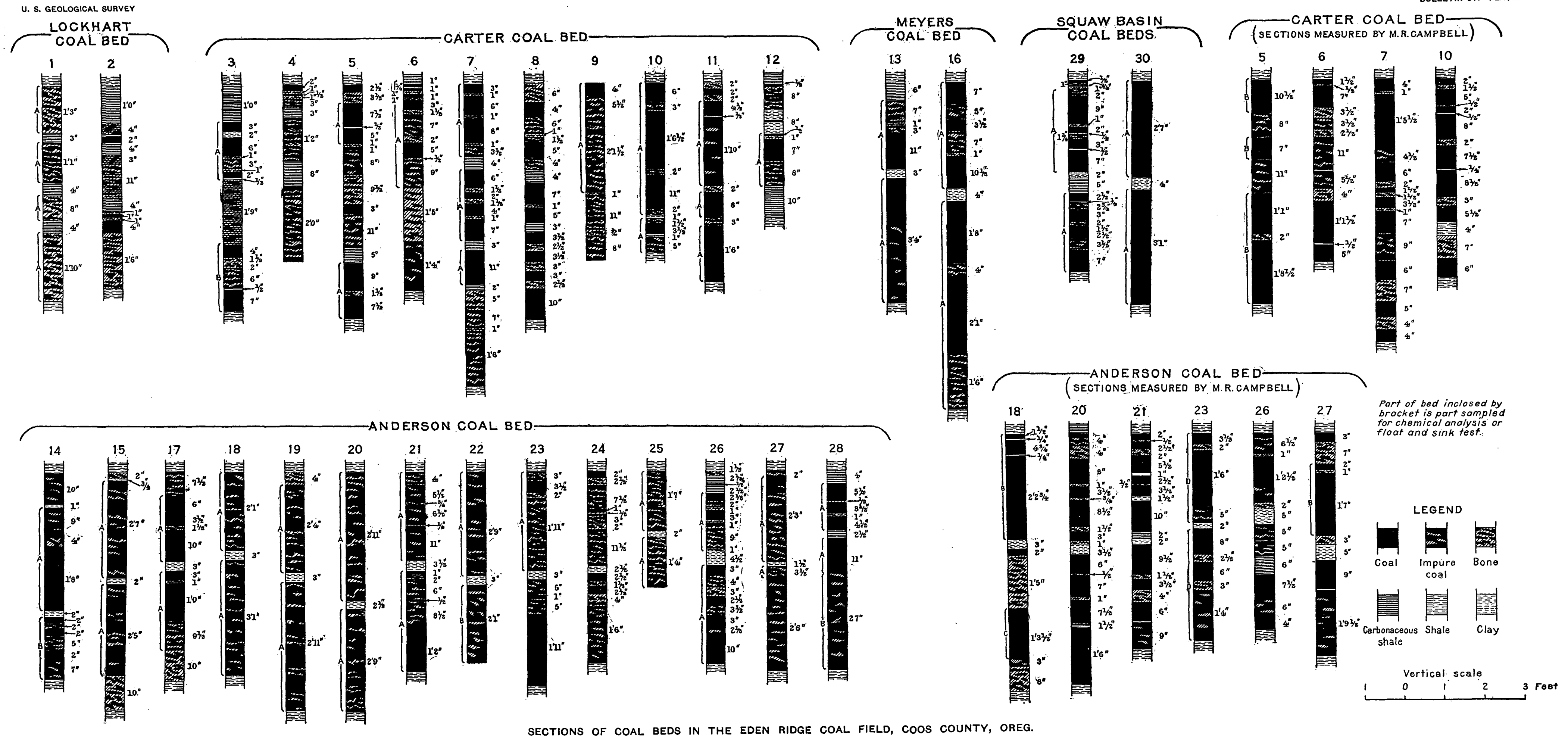
Sections of Anderson coal bed at locations 18 and 21.

[Measured by W. M. Stephens.]

Location 18, NE. sec. 32 , T. 32 S., R. 11 W.

Sandstone, shaly.

Shale and bone

Coal, hard, some bone........

Bone

Coal, hard, bony.

Bone.

Coal, bright

Coal, bony

Coal, hard, bright

Shale, carbonaceous...........

Coal, bright. ..............

Shale, carbonaceous..........

Shale, light sandy, main part ing ${ }^{1}$.

Coal, bright

Coal, shaly.

Coal, hard, bright

Shale, carbonaceous..........

Coal........................

Shale, carbonaceous..........

Coal, some bone.

Shale, soft carbonaceous...

Coal, hard, bony...............

Clay, dark, soft.

Sandstone, shaly.
Ft. in.

Sandstone, shaly.

Shale, carbonaceous.........

Coal, bright................ $\quad 3 \frac{1}{3}$

Shale, carbonaceous.........

Coal....................... 7

Shale and bone.............. 1

Coal..................... 3

Coal and shale interbanded... . 1

Coal....................... 3

Shale, brown............... 1

Coal with shale bands........ 11

29

Shale, main parting, light sandy ${ }^{2} \ldots \ldots \ldots \ldots \ldots \ldots . \quad 2-3$

Coal and shale............ 9

Shale, carbonaceous.......... 2

Coal....................... 4

Shale and bone.............. 3

Coal....................... 5

Coal and shale, soft........... $\quad 10$

Shale.................... 1

Sandstone, shaly.

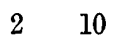

$\overline{5 \quad 9-10}$

Sections of Carter coal bed at locations 5 and 10.

[Measured by W. M. Stephens.]

Location 5, SW. 1 NE. $\frac{1}{2}$ sec. 29 , T. 32 S., R. 11 W. Location 10, SE. $\frac{1}{2}$ SE. $\frac{1}{2}$ sec. 29, T. 32 S., R. 11 W.

Sandstone, shaly.

Coal, bony, and shale interbanded ${ }^{3}$.

Ft. in.

Shale and shaly sandstone. ${ }^{4} \quad$ Ft. in.

Shale and bone............ 10

Coal, bright

3

Shale, parting

Coal.

Coal, shaly .............. 3

n........

Coal, hard and bony ........ 28

Coal....................

Coal, bony................ 5

Bone.

Shale, light.

Coal.....................

Coal. .

Shale, soft.............. 3

Coal......................

Coal, bony .................

Coal.

Coal, shaly, and shale, soft.....

12

Shale, sandy. Shale, sandy.

1 All of bed between roof and floor except this parting was included in sample 18D (laboratory No. 14047). 2 Portion of bed between roof and this parting was included in sample $21 \mathrm{~B}$ (laboratory No. 14045), and portion of bed between this parting and floor was included in sample 21C (laboratory No.14046).

8 All of bed between this bony coal and interbanded shale and the shale floor was included in sample 5C (laboratory No. 14048).

4 All of bed between roof and floor was included in sample 10B (laboratory No. 14049). 
CHEMICAL ANALYSES.

In the accompanying table the analyses are given in four forms, marked A, B, C, and D. Analysis A represents the composition of the sample as it comes from the mine. This form is not well suited for comparison, because the amount of moisture in the sample as it comes from the mine is largely a matter of accident, and consequently analyses of the same coal expressed in this form may vary widely. Analysis B represents the sample after it has been dried at a temperature a little above the normal until its weight becomes constant. This form of analysis is best adapted to general comparisons. Analysis C represents the theoretical condition of the coal after all the moisture has been eliminated. Analysis $\mathrm{D}$ represents the coal after all moisture and ash have been theoretically removed. This is supposed to represent the true coal substance, free from the most significant impurities. Forms $\mathrm{C}$ and $\mathrm{D}$, which represent theoretical conditions that do not actually exist, are obtained from the others by recalculation.

In the analytical work chemists generally recognize that it is not possible to determine the proximate constituents of coal or lignite with the same degree of accuracy as the ultimate constituents. Therefore the air-drying loss, moisture, volatile matter, fixed carbon, and ash are given to one decimal place only. It is also understood that calorific determinations to individual units are not reliable; therefore in the column headed "Calories" the heat values are given to the nearest five units, and in the column headed "British thermal units" they are given to the nearest tens, as the value of a British thermal unit is about one-half that of a calorie. 
Analyses of coal samples from the Eden Ridge and Coos Bay coal fields, Coos County, Oreg.

[Made at the Pittsburgh laboratory of the Bureau of Mines, A. C. Fieldner, chemist in charge.]

Eden Ridge coal field.

\begin{tabular}{|c|c|c|c|c|c|c|c|c|c|c|c|c|c|c|c|c|c|c|c|}
\hline \multirow{2}{*}{$\begin{array}{l}\text { Name of pros- } \\
\text { pect or mine. }\end{array}$} & \multirow{2}{*}{ Collector. } & \multirow{2}{*}{ Coal bed. } & \multicolumn{4}{|c|}{ Location. } & \multicolumn{2}{|c|}{ Thickmess. } & \multirow{2}{*}{$\begin{array}{c}\text { No. } \\
\text { on } \\
\text { Pl. } \\
\mathbf{X X V} .\end{array}$} & \multirow{2}{*}{$\begin{array}{c}\text { Labor- } \\
\text { atory } \\
\text { No. }\end{array}$} & \multirow{2}{*}{$\begin{array}{c}\text { Air- } \\
\text { drying } \\
\text { loss. }\end{array}$} & \multirow{2}{*}{$\left|\begin{array}{c}\text { Form } \\
\text { of } \\
\text { anal- } \\
\text { ysis. }\end{array}\right|$} & \multicolumn{5}{|c|}{ Proximate. } & \multicolumn{2}{|c|}{ Heating value. } \\
\hline & & & $\begin{array}{l}\text { Quar- } \\
\text { ter. }\end{array}$ & Sec. & T. & $\begin{array}{l}\text { R. } \\
\text { W. }\end{array}$ & $\begin{array}{l}\text { Coal } \\
\text { bed. }\end{array}$ & $\begin{array}{l}\text { Part } \\
\text { sam- } \\
\text { pled. }\end{array}$ & & & & & Mois- & $\begin{array}{l}\text { Volatile } \\
\text { matter. }\end{array}$ & $\begin{array}{c}\text { Fixed } \\
\text { carbon. }\end{array}$ & Ash. & $\begin{array}{l}\text { Sul- } \\
\text { phur. }\end{array}$ & $\begin{array}{l}\text { Calo- } \\
\text { ries. }\end{array}$ & $\begin{array}{l}\text { British } \\
\text { thermal } \\
\text { units. }\end{array}$ \\
\hline Hammond.... & W. M. Stephens. . & Carter... & SW. & 29 & 32 & 11 & $\underset{7}{F t . i n .}$ & $\begin{array}{c}\text { Ft. in. } \\
46\end{array}$ & $5 \mathrm{C}$ & 14048 & 3.3 & $\begin{array}{l}\mathrm{A} \\
\mathrm{B} \\
\mathrm{C} \\
\mathrm{D}\end{array}$ & $\begin{array}{r}8.1 \\
5.0 \\
\cdots \cdots . . . \\
\hdashline . . .6\end{array}$ & $\begin{array}{l}32.5 \\
33.6 \\
35.4 \\
52.7\end{array}$ & $\begin{array}{l}29.2 \\
30.2 \\
31.8 \\
47.3\end{array}$ & $\begin{array}{c}30.2 \\
31.2 \\
32.8 \\
\cdots \ldots . .\end{array}$ & $\begin{array}{r}0.35 \\
.36 \\
.38 \\
.57\end{array}$ & $\begin{array}{l}4,610 \\
4,765 \\
5,015 \\
7,470\end{array}$ & $\begin{array}{r}8,300 \\
8,580 \\
9,030 \\
13,440\end{array}$ \\
\hline Do........... & M. R. Campbell.... & ...do......... & $\begin{array}{l}\text { SW. } \\
\text { NE. } \frac{1}{2}\end{array}$ & 29 & 32 & 11 & 6 & $4 \quad 3$ & $5 B$ & 14831 & 3.7 & $\begin{array}{l}\text { A } \\
\text { B } \\
\text { C } \\
\text { D }\end{array}$ & \begin{tabular}{r}
8.0 \\
4.5 \\
$\cdots \cdots .$. \\
\hdashline$\ldots . .$. \\
\end{tabular} & $\begin{array}{l}35.0 \\
36.3 \\
38.0 \\
48.5\end{array}$ & $\begin{array}{l}37.1 \\
38.6 \\
40.4 \\
51.5\end{array}$ & $\begin{array}{c}19.9 \\
20.6 \\
21.6 \\
\cdots \ldots . .\end{array}$ & $\begin{array}{l}.58 \\
.60 \\
.63 \\
.80\end{array}$ & $\begin{array}{l}5,460 \\
5,670 \\
5,940 \\
7,575\end{array}$ & $\begin{array}{r}9,830 \\
10,210 \\
10,690 \\
13,630\end{array}$ \\
\hline Reeves.... & C. E. Lesher........ & ...do........ & $\begin{array}{l}\text { NW. } \\
\text { NW. }\end{array}$ & 28 & 32 & 11 & $81 \frac{1}{2}$ & $4 \quad 9 \frac{1}{2}$ & $7 \mathrm{~A}$ & 17704 & 2.9 & $\begin{array}{l}\mathrm{A} \\
\mathrm{B} \\
\mathrm{C} \\
\mathrm{D}\end{array}$ & \begin{tabular}{r}
8.3 \\
5.6 \\
$\ldots \ldots . .$. \\
\hdashline .2 .6$. \\
\end{tabular} & $\begin{array}{l}26.7 \\
27.5 \\
29.2 \\
49.2\end{array}$ & $\begin{array}{l}27.7 \\
28.5 \\
30.1 \\
50.8\end{array}$ & $\begin{array}{l}37.3 \\
38.4 \\
40.7 \\
\cdots \ldots .\end{array}$ & $\begin{array}{r}.57 \\
.59 \\
.62 \\
1.05\end{array}$ & $\begin{array}{l}3,900 \\
4,015 \\
4,255 \\
7,175\end{array}$ & $\begin{array}{r}7,020 \\
7,230 \\
7,660 \\
12,910\end{array}$ \\
\hline Johnson.......... & W. M. Stephens... & ...do........ & $\begin{array}{l}\mathrm{SE} \cdot \frac{1}{4} \\
\mathrm{SE} \cdot \frac{1}{2}\end{array}$ & 29 & 32 & 11 & $\begin{array}{ll}6 & 1 \frac{1}{2}\end{array}$ & $6 \quad 1 \frac{1}{2}$ & $10 B$ & 14049 & 2.5 & $\begin{array}{l}\mathrm{A} \\
\mathrm{B} \\
\mathbf{C} \\
\mathrm{D}\end{array}$ & $\begin{array}{r}7.2 \\
4.8 \\
\cdots \cdots \\
\cdots . . .2 \\
\end{array}$ & $\begin{array}{l}34.1 \\
34.9 \\
36.7 \\
54.1\end{array}$ & $\begin{array}{l}28.9 \\
29.7 \\
31.2 \\
45.9\end{array}$ & $\begin{array}{l}29.8 \\
30.6 \\
32.1\end{array}$ & $\begin{array}{r}.81 \\
.83 \\
.87 \\
1.28\end{array}$ & $\begin{array}{l}4,720 \\
4,840 \\
5,090 \\
7,500\end{array}$ & $\begin{array}{r}8,500 \\
8,720 \\
9,160 \\
13,500\end{array}$ \\
\hline $\begin{array}{l}\text { Everett Associa- } \\
\text { tion. }\end{array}$ & C. E. Lesher......... & Mreyers.... & $\ldots \ldots$ & $\ldots$ & $a 33$ & 11 & 511 & 52 & $13 \mathrm{~A}$ & 17708 & 12.0 & $\begin{array}{l}\stackrel{A}{A} \\
\stackrel{B}{C} \\
D\end{array}$ & $\begin{array}{r}15.1 \\
3.5 \\
\cdots \ldots . . . \\
\cdots \cdots\end{array}$ & $\begin{array}{l}33.2 \\
37.8 \\
39.2 \\
51.4\end{array}$ & $\begin{array}{l}31.4 \\
35.6 \\
36.9 \\
48.6\end{array}$ & $\begin{array}{l}20.3 \\
23.1 \\
23.9\end{array}$ & $\begin{array}{l}1.29 \\
1.47 \\
1.52 \\
2.00\end{array}$ & $\begin{array}{l}5,020 \\
5,705 \\
5,910 \\
7,770\end{array}$ & $\begin{array}{r}9,040 \\
10,270 \\
10,640 \\
13,990\end{array}$ \\
\hline W. B. Meyers.. & .....do.... & ...do... & & & $a 33$ & 11 & 89 & 85 & $16 \mathrm{~A}$ & 17705 & 5.5 & $\begin{array}{l}\text { A } \\
\text { B } \\
\text { C } \\
\text { D }\end{array}$ & \begin{tabular}{r}
9.2 \\
4.0 \\
$\cdots \ldots . .$. \\
\hdashline$\cdots . .$. \\
\end{tabular} & $\begin{array}{l}34.2 \\
36.2 \\
37.7 \\
51.5\end{array}$ & $\begin{array}{l}32.3 \\
34.2 \\
35.6 \\
48.5\end{array}$ & \begin{tabular}{|l|}
24.3 \\
25.6 \\
26.7
\end{tabular} & $\begin{array}{l}1.68 \\
1.78 \\
1.85 \\
2.52\end{array}$ & $\begin{array}{l}5,110 \\
5,400 \\
5,625 \\
7,675\end{array}$ & $\begin{array}{r}9,190 \\
9,720 \\
10,130 \\
13,810\end{array}$ \\
\hline O. L. Hillis....... & W. M. Stephens... & Anderson. & $\begin{array}{l}\text { SE. } \frac{1}{2} \\
\text { NE. }\end{array}$ & 32 & 32 & 11 & 63 & 6 & $18 \mathrm{D}$ & 14047 & 3.7 & $\begin{array}{l}\mathrm{A} \\
\mathrm{B} \\
\mathrm{C} \\
\mathrm{D}\end{array}$ & $\begin{array}{r}7.6 \\
4.0 \\
\cdots \ldots . . \\
\ldots \ldots . .\end{array}$ & $\begin{array}{l}36.0 \\
37.3 \\
38.9 \\
58.2\end{array}$ & $\begin{array}{l}25.8 \\
26.8 \\
27.9 \\
41.8\end{array}$ & \begin{tabular}{|}
30.6 \\
31.9 \\
33.2 \\
$\ldots \ldots .$.
\end{tabular} & $\begin{array}{l}1.24 \\
1.29 \\
1.34 \\
2.00\end{array}$ & $\begin{array}{l}4,700 \\
4,880 \\
5,080 \\
7,605\end{array}$ & $\begin{array}{r}8,460 \\
8,780 \\
9,150 \\
13,690\end{array}$ \\
\hline
\end{tabular}


Eden Ridge coal fleld-Continued.

\begin{tabular}{|c|c|c|c|c|c|c|c|c|c|c|c|c|c|c|c|c|c|c|c|}
\hline \multirow{2}{*}{$\begin{array}{l}\text { Name of pros- } \\
\text { pect or mine. }\end{array}$} & \multirow{2}{*}{ Collector. } & \multirow{2}{*}{ Coal bed. } & \multicolumn{4}{|c|}{ Location. } & \multicolumn{2}{|c|}{ Thickness. } & \multirow{2}{*}{$\begin{array}{c}\text { No. } \\
\text { on } \\
\text { PI. } \\
X X Y\end{array}$} & \multirow{2}{*}{$\begin{array}{l}\text { Labor- } \\
\text { atory } \\
\text { No. }\end{array}$} & \multirow{2}{*}{$\begin{array}{c}\text { Air- } \\
\text { drying } \\
\text { loss. }\end{array}$} & \multirow{2}{*}{$\begin{array}{c}\text { Form } \\
\text { of } \\
\text { anal- } \\
\text { ysis. }\end{array}$} & \multicolumn{5}{|c|}{ Proximate. } & \multicolumn{2}{|c|}{ Heating value. } \\
\hline & & & $\begin{array}{c}\text { Quar- } \\
\text { ter. }\end{array}$ & Sec. & T. & $\begin{array}{l}\mathrm{R} . \\
\mathrm{w} .\end{array}$ & $\begin{array}{l}\text { Coal } \\
\text { bed. }\end{array}$ & $\begin{array}{l}\text { Part } \\
\text { sam- } \\
\text { pled. }\end{array}$ & & & & & $\begin{array}{l}\text { Mois- } \\
\text { ture. }\end{array}$ & $\begin{array}{c}\text { Volatile } \\
\text { matter. }\end{array}$ & $\begin{array}{l}\text { Fixed } \\
\text { carbon. }\end{array}$ & Ash. & $\begin{array}{c}\text { Sul- } \\
\text { phur. }\end{array}$ & $\begin{array}{l}\text { Calo- } \\
\text { ries. }\end{array}$ & $\begin{array}{c}\text { British } \\
\text { thermal } \\
\text { units. }\end{array}$ \\
\hline O. L. Hillis.. & M. R. Campbell.. & Anderson. & $\begin{array}{l}\text { SE. } \\
\text { NE. }\end{array}$ & 32 & 32 & 11 & $\begin{array}{l}\text { Ft. in. } \\
6 \text { io }\end{array}$ & $\begin{array}{ll}\text { Ft. in. } \\
1 & 3 \frac{1}{2}\end{array}$ & $18 \mathrm{C}$ & 14827 & 6.7 & $\begin{array}{l}\text { A } \\
\text { B } \\
\text { C } \\
\text { D }\end{array}$ & $\begin{array}{r}10.0 \\
3.5 \\
\cdots \ldots . . \\
\ldots . . .\end{array}$ & $\begin{array}{l}38.5 \\
41.2 \\
42.7 \\
51.4\end{array}$ & $\begin{array}{l}36.3 \\
39.0 \\
40.4 \\
48.6\end{array}$ & $\begin{array}{l}15.2 \\
16.3 \\
16.9\end{array}$ & $\begin{array}{r}0.63 \\
.68 \\
.70 \\
.84\end{array}$ & $\begin{array}{l}5,850 \\
6,270 \\
6,495 \\
7,820\end{array}$ & $\begin{array}{l}10,530 \\
11,280 \\
11,690 \\
14,070\end{array}$ \\
\hline Do..... & .....do............ & ...do........ & $\begin{array}{l}\text { SE. } \\
\text { NE. } \frac{1}{\frac{1}{2}}\end{array}$ & 32 & 32 & 11 & 610 & $29 \frac{1}{2}$ & $18 \mathrm{~B}$ & 14830 & 3.3 & $\begin{array}{l}\mathbf{A} \\
\mathbf{B} \\
\mathbf{C} \\
\mathbf{D}\end{array}$ & 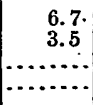 & $\begin{array}{l}35.5 \\
36.7 \\
38.1 \\
56.4\end{array}$ & $\begin{array}{l}27.4 \\
28.4 \\
29.4 \\
43.6\end{array}$ & $\begin{array}{l}30.4 \\
31.4 \\
32.5\end{array}$ & $\begin{array}{l}2.2 \\
2.3 \\
2.4 \\
3.5\end{array}$ & $\begin{array}{l}4,750 \\
4,910 \\
5,090 \\
7,550\end{array}$ & $\begin{array}{r}8,550 \\
8,840 \\
9,170 \\
13,590\end{array}$ \\
\hline Gant......... & W. M. Stephens... & ...do........ & $\begin{array}{l}\text { SW. } \\
\text { SE. }\end{array}$ & 28 & 32 & 11 & 510 & 29 & $21 \mathrm{~B}$ & 14045 & 3.6 & $\begin{array}{l}\mathbf{A} \\
\mathbf{B} \\
\mathbf{C} \\
\mathbf{D}\end{array}$ & \begin{tabular}{r}
7.3 \\
3.9 \\
$\cdots \cdots$ \\
\hdashline$\cdots$ \\
\end{tabular} & $\begin{array}{l}33.5 \\
34.7 \\
36.1 \\
56.2\end{array}$ & $\begin{array}{l}26.1 \\
27.1 \\
28.2 \\
43.8\end{array}$ & $\begin{array}{c}33.1 \\
34.3 \\
35.7 \\
\cdots . . .\end{array}$ & $\begin{array}{l}2.5 \\
2.6 \\
2.7 \\
4.2\end{array}$ & $\begin{array}{l}4,530 \\
4,700 \\
4,890 \\
7,605\end{array}$ & $\begin{array}{r}8,160 \\
8,460 \\
8,800 \\
13,690\end{array}$ \\
\hline Do........... & .....do........... & ...do....... & SW. $\frac{1}{\text { SE. }}$ & 28 & 32 & 11 & 510 & 210 & $21 \mathrm{C}$ & $\begin{array}{c}14046 \\
.\end{array}$ & 6.2 & $\begin{array}{l}\mathrm{A} \\
\mathrm{B} \\
\mathrm{C} \\
\mathrm{D}\end{array}$ & \begin{tabular}{r}
10.2 \\
4.2 \\
$\cdots$ \\
\hdashline$\ldots \ldots$. \\
\end{tabular} & $\begin{array}{l}33.3 \\
35.5 \\
37.0 \\
56.2\end{array}$ & $\begin{array}{l}26.0 \\
27.6 \\
28.9 \\
43.8\end{array}$ & $\begin{array}{c}30.5 \\
32.7 \\
34.1 \\
\cdots \cdots\end{array}$ & $\begin{array}{l}1.1 \\
1.2 \\
1.2 \\
1.9\end{array}$ & $\begin{array}{l}4,485 \\
4,780 \\
4,990 \\
7,580\end{array}$ & $\begin{array}{r}8,070 \\
8,610 \\
8,990 \\
13,640\end{array}$ \\
\hline J. H. Flanigan... & M. R. Campbell... & ...do........ & $\mid \begin{array}{l}N W \cdot \frac{1}{6} \\
\cdot N E \cdot \frac{1}{2}\end{array}$ & 28 & 32 & 11 & 56 & 54 & $23 \mathrm{D}$ & 14828 & 6.2 & $\begin{array}{l}\mathbf{A} \\
\mathbf{B} \\
\mathbf{C} \\
\mathbf{D}\end{array}$ & $\begin{array}{r}10.1 \\
4.2 \\
\cdots \ldots . .\end{array}$ & $\begin{array}{l}31.3 \\
33.4 \\
34.8 \\
55.7\end{array}$ & $\begin{array}{l}24.9 \\
26.5 \\
27.7 \\
44.3\end{array}$ & $\begin{array}{c}33.7 \\
35.9 \\
37.5 \\
\cdots \ldots . .\end{array}$ & $\begin{array}{l}1.1 \\
1.2 \\
1.2 \\
2.0\end{array}$ & $\begin{array}{l}4,150 \\
4,420 \\
4,615 \\
7,375\end{array}$ & $\begin{array}{r}7,470 \\
7,960 \\
8,310 \\
13,280\end{array}$ \\
\hline Vanderpool....... & ....do......... & ...do........ & $\begin{array}{l}\text { NW. } \\
\text { NE. }\end{array}$ & 30 & 32 & 11 & $510 \frac{1}{2}$ & 110 & 27B & 14829 & 3.3 & $\begin{array}{l}\text { A } \\
\text { B } \\
\text { C } \\
\text { D }\end{array}$ & $\begin{array}{l}7.3 \\
4.1\end{array}$ & $\begin{array}{l}37.6 \\
38.9 \\
40.6 \\
57.7\end{array}$ & $\begin{array}{l}27.6 \\
28.5 \\
29.7 \\
42.3\end{array}$ & $\begin{array}{r}.27 .5 \\
28.5 \\
29.7 \\
\cdots \cdots . .\end{array}$ & $\begin{array}{l}2.6 \\
2.7 \\
2.8 \\
4.0\end{array}$ & $\begin{array}{l}4,915 \\
5,085 \\
5,305 \\
7,540\end{array}$ & $\begin{array}{r}8,850 \\
9,150 \\
9,550 \\
13,580\end{array}$ \\
\hline G. W. Donnell .. & C. E. Lesher.... & (?)... & & $\ldots$ & $a 33$ & 11 & $5 \quad 1 \frac{1}{6}$ & $43 \frac{1}{2}$ & $29 \mathrm{~A}$ & 17706 & 6.8 & $\begin{array}{l}\mathbf{A} \\
\mathbf{B} \\
\mathbf{C} \\
\mathrm{D}\end{array}$ & $\begin{array}{r}10.8 \\
4.3 \\
\ldots \ldots\end{array}$ & $\begin{array}{l}30.9 \\
33.2 \\
34.7 \\
49.3\end{array}$ & $\begin{array}{l}31.8 \\
34.1 \\
35.6 \\
50.7\end{array}$ & $\begin{array}{l}26.5 \\
28.4 \\
29.7\end{array}$ & $\begin{array}{l}1.0 \\
1.1 \\
1.1 \\
1.6\end{array}$ & $\begin{array}{l}4,820 \\
5,170 \\
5,405 \\
7,690\end{array}$ & $\begin{array}{r}8,680 \\
9,310 \\
9,720 \\
13,840\end{array}$ \\
\hline
\end{tabular}




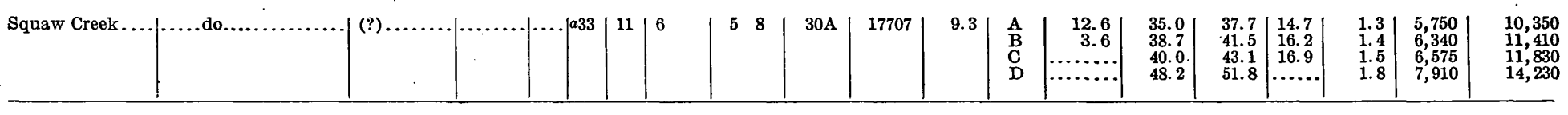

Coos Bay coal fleld.

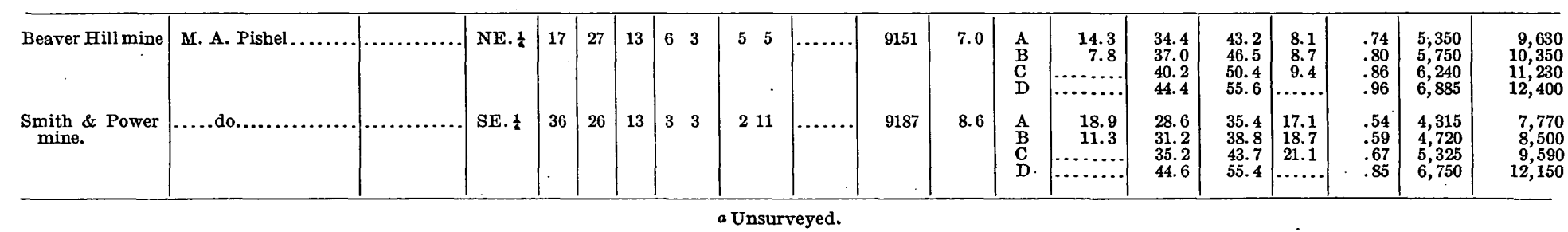


The analyses illustrate the great variability of these coals from place to place. Sulphur determinations by the Bureau of Mines on 26 samples from all the beds in the field show a minimum of 0.36 per cent, a maximum of 3.51 per cent, and an average of 1.26 per cent. In 25 samples the moisture in the air-dried condition ranged from 2.9 to 7.3 per cent, the average being 4 per cent. In 15 samples of the Anderson bed the ash ranged from 16.3 to 40.2 per cent, the average being 31 per cent. In 9 samples of the Carter bed the ash ranged from 20.6 to 45.9 per cent, the average being 34.5 per cent. The Meyers bed contains about 24 per cent ash; the two analyses of Squaw Basin coals show 16 and 28 per cent ash.

The analyses differ widely in respect to ash content and heating value, as stated above. A study of form D, however, which represents the coal material free from moisture and ash, shows that the heating value of the material itself is very uniform and averages over 13,000 British thermal units. This suggests that if coal beds containing less bone and shale could be discovered in the field, or if the coal in the beds here discussed could be mechanically purified, the resulting fuel would be of high grade.

Comparison of the analyses with those of the Coos Bay coals shows that the latter are lower in ash and in heat value and higher in moisture than the coals in the Eden Ridge field. The Coos Bay coals contain on an average less than half the amount of ash and from two to three times the amount of moisture found in the Eden Ridge coals. The heat value of the coals calculated on the ash and moisture-free basis, form D, shows that the Coos Bay coals contain 12,150 and 12,400 British thermal units as compared with the Eden Ridge coals, which contain on an average between 13,500 and 14,000 British thermal units. A study of the analyses of the Eden Ridge coals shows that the heat value of the samples in the air-dried condition is nearly in inverse proportion to the ash content. This relation is expressed graphically in the accompanying diagram (fig. 15).

The empirical formula of Parr and Wheeler for "unit coal" 1 was applied to ten analyses, Nos. 14045-14049 and 14827-14831, and the results averaged to determine the line $\mathrm{A}-\mathrm{B}$ on this diagram. Analyses Nos. 17704-17708 have since become available and have been plotted on this diagram. By means of the diagram the heat value (within 200 British thermal units) of an unweathered sample of coal from this field can be ascertained directly from the percentage of ash, so that only the latter need be determined by analysis. For ex-

\footnotetext{
1 Parr, S. W., and Wheeler, W. F., Unit coal and the composition of coal ash: University of Illinois Bull. No. 37, 1909.

Formula for heat value of unit coal:

British thermal units of unit coal $=\frac{\text { Indicated British thermal units }-5,000 \frac{\text { Per cent sulphur }}{100}}{1-\left(\frac{\text { per cent moisture }}{100}+1.08 \frac{\text { per cent ash }}{100}+\frac{22}{40} \frac{\text { per cent sulphur }}{100}\right)}$
} 
ample: To determine the approximate heat value of a sample containing 30 per cent ash, follow the horizontal line corresponding to 30 per cent on the left-hand vertical scale to its intersection with the line A-B. From this intersection follow the vertical line down to the horizontal scale at the bottom. The result is 9,000 British thermal units. That is, if a sample in the air-dried condition contains 30 per cent ash it may be confidently inferred that it yields approximately 9,000 British thermal units. In like manner a sample containing 10 per cent ash has approximately 12,000 British thermal units. Because of this practical value the diagram is given in the preliminary paper, but a description of the calculations involved in locating the line $\mathrm{A}-\mathrm{B}$ and a discussion of the interpretation of the results obtained will be reserved for a final report, to be published later.

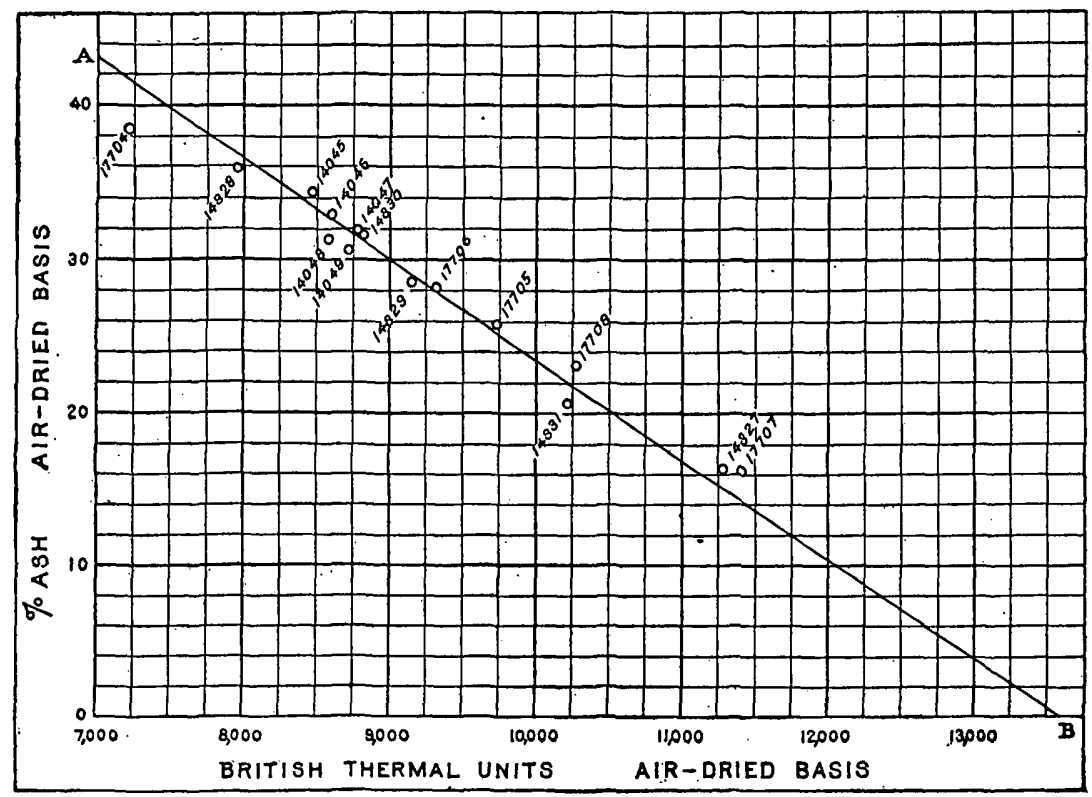

Frgure 15.-Diagram showing relation between percentage of ash and heating value of coal from the Eden Ridge fleld, Oreg. Numbers along line A-B are laboratory numbers of analyses.

The high ash content in the Anderson and Carter beds, averaging about 30 per cent, is of course a decided detriment, and if not at least partly removable would probably prohibit their use for domestic fuel or for making steam. It is doubtful whether or not they could be profitably utilized as mined, even in the gas producer. An examination of the Eden Ridge coal beds shows that their high ash content is primarily due to the presence of bone and bony coal occurring in layers between the benches of coal. This bone contains 40 to 50 per cent of ash, and its removal would leave a coal material much lower in ash than the average of the bed as mined. A common method of separating bone from coal and thus improving its quality 
is washing. Bone and impure coal have a higher specific gravity than coal, and it is this physical fact on which the successful washing depends. As the Eden Ridge coals have not been commercially washed, the only means by which to judge of their adaptability to this method of cleaning is by float and sink tests. The results of investigations of the United States Geological Survey and.Bureau of Mines ${ }^{1}$ and the Canada Department of Mines ${ }^{2}$ are considered to have demonstrated the adequacy of float and sink tests, properly interpreted, as an index of the adaptability of coal to commercial washing. The results of the float and sink tests and field analyses of coal in the Eden Ridge field made by the writer are given in the following table:

1 Belden, A. W., Delamater, G. R., Groves, J. W., and Way, K. M., Washing and coking tests of coal at the fuel-testing plant, Denver, Colo., July 1, 1908, to June 30, 1909: Bureau of Mines Bull. 5, 1910.

2 Porter, J. B., and Durley, R. J., An investigation of the coals of Canada with reference to their economic qualities: Canada Dept. Mines, Mines Branch, vol. 1, 1912. 
Results of float and sink tests and field analyses of coal in the Eden Ridge coal field, Oreg.

[Tests and analyses by C. E. Lesher.]

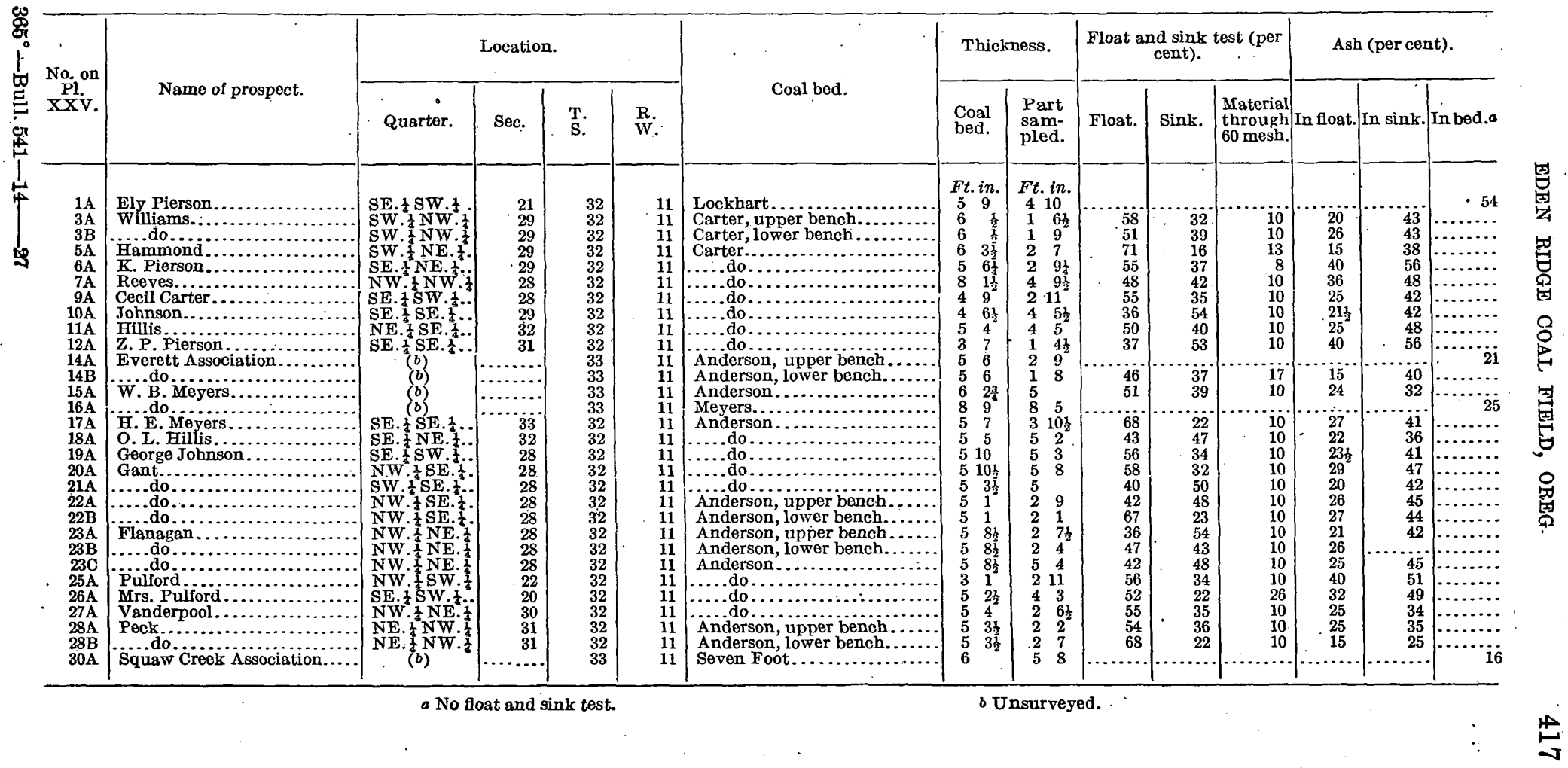


In taking each sample for these tests the. writer endeavored to obtain if possible a sample that would represent a minable portion of the bed. The tests were made on approximately 1 pound of coal broken into fragments one-fourth of an inch or less in size. All material finer than 60 mesh was screened and discarded, and the remainder was separated into float and sink in a calcium-chloride solution of 1.35 specific gravity. The column of liquid in which the separation was made was 8 inches high, and the division between float and sink was made $2 \frac{1}{2}$ inches from the bottom; that is, after the sample had come to rest in the apparatus all the material in the upper $5 \frac{1}{2}$ inches was taken out and treated as float, and all the material in the lower $2 \frac{1}{2}$ inches was treated as sink.

The average thickness sampled in each prospect on the Anderson bed on the south side of Eden Ridge (see secs. 14, 15, 17-23, and $28, \mathrm{Pl} . \mathrm{XXV}$ ) is 59 inches, and the results of the tests as given above show in these samples an average of 54.2 per cent float with an approximate heating value of 10,000 British thermal units, and 45.8 per cent sink, which is probably worthless. The average thickness sampled on the Anderson bed on the north side of the ridge in prospects 25,26 , and 27 is 35 inches, and of the material in the samples 54 per cent was float with an approximate heating value of 8,500 British thermal units. The average thickness sampled in eight prospects on the Carter bed (see secs. 3, 5, 6, 7, and 9-12, Pl. XXV) is 36 inches, and the average of the results of the float and sink tests of these samples show that 50 per cent of the material is float with an approximate heating value of 9,500 British thermal units.

The tests thus indicate that in the greater part of the field the Anderson and Carter beds, though very bony, will yield to mechanical purification and will give a washed product, representing 50 to 60 per cent of the tonnage mined, which will contain from 15 to $25 \mathrm{per}$ cent ash and have a heat value of 9,500 to over 10,000 British thermal units. Inasmuch, however, as the material must be broken into fragments less than 1 inch in diameter before being washed it is evident that the marketable coal will be in small fragments. Abundant water, a prime necessity in coal washing, is available in this field.

The best coal so far found in the field is at location 30 in Squaw Basin. Analysis No. 17707 shows it to contain 16 per cent ash and to have a heating value of more than 11,100 British thermal units. Although coking tests by the Bureau of Mines on samples from locations 29 and 30 gave negative results, selected portions of these beds were coked by the writer in a blacksmith forge. It is very probable that if the bone, though small in amount, were cleaned from the coal it could be commercially coked. 